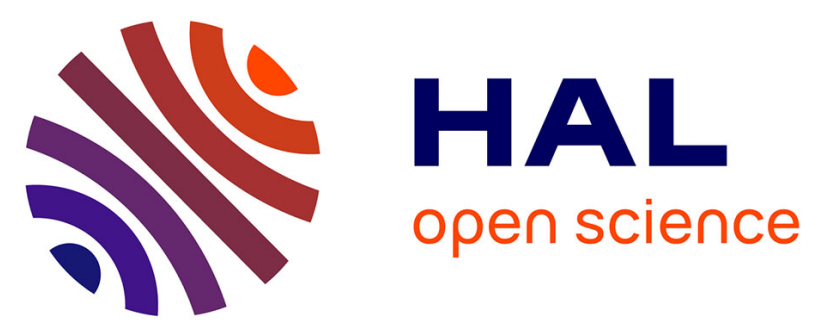

\title{
Effects of temperature and p CO 2 on the respiration, biomineralization and photophysiology of the giant clam Tridacna maxima
}

Chloé Brahmi, Leila Chapron, Gilles Le Moullac, Claude Soyez, Benoît Beliaeff, Claire E Lazareth, Nabila Gaertner-Mazouni, Jeremie Vidal-Dupiol

\section{To cite this version:}

Chloé Brahmi, Leila Chapron, Gilles Le Moullac, Claude Soyez, Benoît Beliaeff, et al.. Effects of temperature and p CO 2 on the respiration, biomineralization and photophysiology of the giant clam Tridacna maxima. 2021. hal-03239758

\author{
HAL Id: hal-03239758 \\ https://hal.science/hal-03239758 \\ Preprint submitted on 27 May 2021
}

HAL is a multi-disciplinary open access archive for the deposit and dissemination of scientific research documents, whether they are published or not. The documents may come from teaching and research institutions in France or abroad, or from public or private research centers.
L'archive ouverte pluridisciplinaire HAL, est destinée au dépôt et à la diffusion de documents scientifiques de niveau recherche, publiés ou non, émanant des établissements d'enseignement et de recherche français ou étrangers, des laboratoires publics ou privés. 
1 Effects of temperature and $\mathrm{pCO}_{2}$ on the respiration, biomineralization and photophysiology of the giant clam Tridacna maxima

3

4

5

6

7

$11{ }^{1}$ Université de la Polynésie française, Ifremer, ILM, IRD, EIO UMR 241, Faa'a, Tahiti, French Polynesia

$122^{2}$ Ifremer, UMR 241 EIO, Labex Corail, Centre du Pacifique, BP 49, 98719 Taravao, Tahiti, French

13 Polynesia

$14{ }^{3}$ Sorbonne Université, CNRS, Laboratoire d'Ecogéochimie des Environnements Benthiques, LECOB, 15 F-66650, Banyuls-sur-mer, France

$16{ }^{4}$ Biologie des Organismes et Écosystèmes Aquatiques (BOREA), Muséum National d'Histoire 17 Naturelle, Sorbonne Université, Université de Caen Normandie, Université des Antilles, CNRS, IRD, 61

18 rue Buffon, CP 53, 75231 Paris, France

$19{ }^{5}$ IHPE, Univ. Montpellier, CNRS, Ifremer, Univ. Perpignan Via Domitia, Montpellier France 20

21 * Corresponding author: chloe.brahmi@upf.pf 


\section{Abstract}

23 Such as many other reef organisms, giant clams are today confronted to global change effects and can 24 suffer mass bleaching or mortality events mainly related to abnormally high seawater temperatures. 25 Despite its strong ecological and socio-economical importance, its responses to the two most alarming threats linked to global change (i.e., ocean warming and acidification) still need to be explored. We investigated physiological responses of 4-years-old Tridacna maxima specimens to realistic levels of temperature and partial pressure of carbon dioxide $\left(\mathrm{pCO}_{2}\right)\left(+1.5^{\circ} \mathrm{C}\right.$ and $+800 \mu$ atm of $\left.\mathrm{CO}_{2}\right)$ predicted for 2100 in French Polynesian lagoons during the warmer season. During a 65-days crossed-factor experiment, individuals were exposed to two temperatures $\left(29.2^{\circ} \mathrm{C} ; 30.7^{\circ} \mathrm{C}\right)$ and two $p \mathrm{CO}_{2}(430 \mu \mathrm{atm}$; $1212 \mu \mathrm{atm})$ conditions. Impact of each parameter and their potential synergetic effect were evaluated on respiration, biomineralization and photophysiology. Kinetics of thermal and acidification stress were evaluated by performing measurements at different times of exposure $\left(29,41,53,65\right.$ days). At $30.7^{\circ} \mathrm{C}$, the holobiont $\mathrm{O}_{2}$ production, symbiont photosynthetic yield, and density were negatively impacted. High $p \mathrm{CO}_{2}$ had a significant negative effect on shell growth rate, symbiont photosynthetic yield and density. Shell microstructural modifications were observed from 41 days in all temperature and $p \mathrm{CO}_{2}$ conditions. No significant synergetic effect was found. Today thermal conditions $\left(29.2^{\circ} \mathrm{C}\right)$ appeared to be sufficiently stressful to induce a host acclimatization process. All these observations indicate that temperature and $p \mathrm{CO}_{2}$ are both forcing variables affecting $T$. maxima physiology and jeopardize its survival under environmental conditions predicted for the end of this century.

Keywords: Thermal stress, ocean acidification, respiration, photosynthetic yield, giant clam, symbionts 


\section{Introduction}

Since the industrial revolution, human activities released gigatons of $\mathrm{CO}_{2}$ in the atmosphere, which participate to global change (Broeker et al., 1979; Caldeira and Wickett, 2003; Sabine et al., 2004; Zeebe et al., 2008; IPCC, 2014). Due to the "greenhouse gas" property of $\mathrm{CO}_{2}$, terrestrial and sea surface temperature rise constantly (i.e., global warming). According to the last Intergovernmental Panel on Climate Change report (IPCC, 2018), human-induced warming had already reached about $+1^{\circ} \mathrm{C}$ above pre-industrial levels and the panel predicts $+1.5^{\circ} \mathrm{C}$ around 2040 if the current warming rate continues. Enrichment of dissolved $\mathrm{CO}_{2}$ in the ocean modifies the carbonate chemistry by depressing carbonate ion concentration $\left(\left[\mathrm{CO}_{3}{ }^{2-}\right]\right)$ and releasing protons which respectively decrease calcium carbonate saturation state $(\Omega)$ and seawater $\mathrm{pH}$ (Kleypas et al., 1999; Caldeira and Wickett, 2003) (i.e., ocean acidification). Indeed, $\mathrm{pH}$ had already decreased by $0.1 \mathrm{pH}$ unit since the pre-industrial revolution and the decrease may reach -0.3 to $-0.4 \mathrm{pH}$ unit by 2100 (according to the median scenario RCP 4.5, IPCC, 2014).

Since $\mathrm{CO}_{3}{ }^{2-}$ is a carbonate ion form involved in biologically controlled calcification process (i.e., biomineralization) (Orr et al., 2005), marine organisms which form calcium carbonate structures (e.g., exoskeleton, shell, test, spicule), such as scleractinian corals, mollusks, and echinoderms are particularly vulnerable to ocean acidification (Hoegh-Guldberg et al., 2007; Ries et al., 2009; Kroeker et al., 2013; Gazeau et al., 2013). Among marine calcifying mollusks, negative impacts of temperature and $\mathrm{pCO}_{2}$ have been demonstrated on the survival, growth, biomineralization processes, and others key physiological functions on different stages of their life cycle (Bougrier et al., 1995; Kurihara, 2008; Gazeau et al., 2010, 2011; Schwartzmann et al., 2011; Rodolfo-Metalpa et al., 2011; Talmage and Gobler, 2011; Watson et al., 2012; Liu et al., 2012; Kuhihara et al., 2013; Fitzer et al., 2014; Le Moullac et al., 2016a,b; Wessel et al., 2018). However, effects of each stressor and their potential synergetic effect on giant clam physiology are still poorly known.

Giant clams live in obligatory symbiosis with photosynthetic dinoflagellates of the family Symbiodiniaceae (Holt et al., 2014; LaJeunesse et al., 2018). Different giant clam species, i.e., Tridacna maxima, Tridacna crocea, Tridacna noae and Tridacna squamosa, have been found to associate with different Symbiodiniaceae genera, i.e., Symbiodinium (formerly clade A, LaJeunesse et al., 2018), Cladocopium (formerly clade C, LaJeunesse et al., 2018) and Durusdinium (formerly clade D, LaJeunesse et al., 2018) (Pinzón et al., 2011; DeBoer et al., 2012; Ikeda et al., 2017; Lim et al., 2019). Hereafter, the symbiotic Symbiodiniaceae are named "symbionts". In giant clams, symbionts are located extracellularly inside a tubular system called "Z-tubules" found in the outer epithelium of the mantle and connected to the stomach (Norton et al., 1992; Holt et al., 2014). These mixotrophic organisms acquire nutrients from heterotrophic (via seawater filtration) and symbionts photo-autotrophic pathways (Klumpp et al., 1992; Hawkins and Klumpp, 1995). Nutrients provided by symbionts (such as glucose, Ishikura et al., 1999) may account for a major part of the clam energy needs depending on the species and life stage (Trench et al., 1981; Klumpp et al., 1992; Klumpp and Lucas, 1994; Klumpp and Griffits, 1994; Hawkins and Klumpp, 1995; Elfwing et al., 2002; Yau and Fan, 2012; Holt et al., 2014; Soo and Todd, 2014). Like symbiotic coral species, bleaching events affecting giant clam have been recorded several times in the Indo-Pacific Ocean (Adessi, 2001; Buck et al., 2002; Leggat et al., 2003; Andréfouët et al., 
2013; Junchompoo et al., 2013) mainly due to seawater temperature increase by a few degrees above the seasonal maximum (Adessi, 2001; Andréfouët et al., 2013). Bleaching process results from the symbiosis breakdown via the loose of symbiotic Symbiodiniaceae (Buck et al., 2002; Leggat et al., 2003).

In French Polynesia, Tridacna maxima species (Röding, 1798) is one of the most emblematic and patrimonial organisms. They represent an important food resource for inhabitants of remote atolls and giant clam fishery and sustainable aquaculture activities generate substantial incomes for local fishermen and farmers (Van Wysberge et al., 2016; Andréfouët et al., 2017). However, wild and cultivated giant clam stocks are largely threatened by environmental disturbances such as abnormally high sea surface temperature inducing mass mortality events as reported in Tuamotu atolls by Adessi (2001) and Andréfouët et al. (2013). More recently, two mass bleaching events occurring in Reao and Tatakoto (Tuamotu islands) were linked to a prolonged high lagoonal temperature $\left(\geq 30^{\circ} \mathrm{C}\right.$ over several weeks) of these semi-closed atolls (Andréfouet et al., 2017; Fig. S1). All these observations strongly indicate that temperature is an important stressor for giant clams. Besides the ecological consequences, giant clam mass bleaching and mortality cause a significant loss of incomes for the islanders.

Despite their ecological and socio-economic importance, effects of thermal stress and acidification on giant clams still need to be investigated. Thermal stress has shown to decrease fertilization success (Amstrong, 2017) in Tridacna maxima and oxygen production and respiration rates in $T$. gigas and $T$. deresa species (Blidberg et al., 2000). In contrast, an increase of respiration with a high photosynthetic rate in the holobiont was reported for T. squamosa (Elfwing et al., 2001). Thermal stress also reduces the abundance of symbionts in T. gigas (Leggat et al., 2003) even after only $12 \mathrm{~h}$ of exposure in T. crocea (Zhou et al., 2018) and a decrease of photosynthate export from symbionts to the host (Leggat et al., 2003). In T. maxima, heat stress induced changes of fatty acid composition and lipid pathways and ROS (Reactive Oxygen Species) scavenger overexpression (Dubousquet et al., 2016). Combined to high light intensities, heat stress caused a decrease of the cell size of remaining symbionts and of their chlorophyll content (Buck et al., 2002). Recent studies demonstrated that low pH seawater with high nutrient concentration could have variable effects on growth on four species of Tridacna genus (Toonen et al., 2012). Moreover, Watson (2015) showed that high light irradiance condition limits the impact of $p \mathrm{CO}_{2}$ on shell growth. Regarding the potential synergetic effect of temperature and $p \mathrm{CO}_{2}$ parameters, the only study ever carried out showed that ocean warming and acidification may reduce survival in T. squamosa juveniles (Waston et al., 2012). To our knowledge, no study had already investigated impact of both parameters, and their potential synergetic effect, on several key physiological parameters of both Tridacna maxima host and its symbionts. To fill this gap, our experimental approach was designed to better understand the physiological mechanisms underlying the response of giant clams to global climate changes.

Based on a 65 days crossed-factor experiment, we investigated physiological responses of 4-years-old Tridacna maxima specimens to temperature and $\mathrm{pCO}_{2}$ conditions in the French Polynesian lagoons during the today warmer season and those predicted for 2100 by the IPCC $2014:+1.5^{\circ} \mathrm{C}$ (RCP 4.5 scenario) and $+800 \mu \mathrm{atm}$ of $\mathrm{CO}_{2}$ (RCP 8.5 scenario). Effect of each parameter and their potential synergetic effect were evaluated on respiration, biomineralization, and photophysiology by analyzing 
123 the holobiont $\mathrm{O}_{2}$ production and respiration, growth rate and ultrastructure of the shell and symbiont 124 density and photosynthetic yield. In addition, the kinetics of thermal and acidification stress were accessed by performing analyses at different time of exposure (i.e., 29, 41, 53, 65 days).

\section{Materials and Methods}

\section{2.1. Biological material}

129 Tridacna maxima specimens of 4-years-old, 5-6 cm height and brownish/dark-green color, were 130 collected in early January 2016 from the cultivated stock in Reao lagoon (Tuamotu islands) and exported

131 to the Centre Ifremer du Pacifique in Tahiti where they were acclimatized in outdoor tank with running 132 seawater. Each individual was placed onto a petri dish on which byssal gland further developed for 133 fixation. All individuals directly opened up right after their transfer into the outdoor tank. No visual sign 134 of stress was observed during the acclimation period except for 4 individuals which died within the first 1353 days (corresponding to a $2 \%$ mortality rate). Specimens used in this study were collected and held 136 under a special permit (MEI \#284) delivered by the French Polynesian government.

\subsection{Experimental design and rearing system}

139 To study the impact of temperature, $p \mathrm{CO}_{2}$, and their putative synergetic effect on the physiology of the 140 giant clams and their symbionts, four experimental conditions were set up by applying two temperatures $141\left(29.2^{\circ} \mathrm{C}\right.$ and $\left.30.7^{\circ} \mathrm{C}\right)$ and two levels of $\mathrm{pCO}_{2}(430 \pm 22 \mu \mathrm{atm}$ and $1212 \pm 35 \mu \mathrm{atm})$. The tested conditions 142 were: (1) control: $29.2^{\circ} \mathrm{C} 430 \mu$ atm, (2) acidification stress: $29.2^{\circ} \mathrm{C} 1212 \mu$ atm), (3) thermal stress: $14330.7^{\circ} \mathrm{C} 430 \mu \mathrm{atm},(4)$ acidification and thermal stress: $30.7^{\circ} \mathrm{C} 1212 \mu \mathrm{atm}$ (Table 1).

144 After a 3 weeks acclimation period in an outdoor tank, 96 clams were randomly distributed in 145 experimental tanks one week before starting the experiment. For each condition, we used a $500 \mathrm{~L}$ tank 146 containing 4 tanks of $30 \mathrm{~L}$ (ecological replicates) renewed at a flow rate of $50 \mathrm{~L} / \mathrm{h}$ (seawater pumped in 147 the lagoon). Each $30 \mathrm{~L}$ tank contained 6 clams (biological replicates). To avoid physiological shock, 148 targeted temperature and $p \mathrm{CO}_{2}$ values were linearly achieved over 7 days. The light was set to obtain 149 a Photosynthetically Active Radiation (PAR) of $200 \pm 20 \mu \mathrm{mol}$ of photons. $\mathrm{m}^{-2} \cdot \mathrm{s}^{-1}$ on a $12 \mathrm{~h}: 12 \mathrm{~h}$ light/dark 150 photoperiod. To evaluate the kinetics of the thermal and/or acidification stress, analyses were performed 151 at 4 different times of exposure, i.e., 29, 41, 53 and 65 days. In total, 64 clams were used for data 152 acquisition corresponding to 4 individuals per condition (1 individual per $30 \mathrm{~L}$ tank) and per time of 153 exposure.

\subsection{Monitoring of temperature, $\mathrm{pH}$ and water quality}

156 To insure the stability of experimental conditions, temperature and $\mathrm{pH}$ parameters were measured twice 157 a day for each tank at 8:00 am and 4:00 pm using a mercury thermometer (certified ISO $9001, \pm 0.1^{\circ} \mathrm{C}$ 158 accuracy) and a pH-meter Consort P603 ( \pm 0.01 accuracy). Total alkalinity (TA) was weekly titrated using 159 a $0.01 \mathrm{~N} \mathrm{HCl}$ solution and a titrator (Schott Titroline Easy). Levels of $\mathrm{pCO}_{2}$ and aragonite saturation 160 state were calculated from temperature, $\mathrm{pH}$ (NBS scale), salinity and mean TA using the $\mathrm{CO}_{2}$ Systat 161 software (van Heuven et al., 2009). All parameters including seawater carbonate chemistry are reported 162 in Table 1. 


\subsection{Holobiont $\mathrm{O}_{2}$ consumption and production measurements}

165 Giant clams were placed in an ecophysiological measurement system (EMS) to monitor $\mathrm{O}_{2}$ consumption and production. The EMS consisted in five open-flow chambers. Four giant clams were individually placed into 4 chambers while an empty shell was placed into a fifth chamber used as a control. EMS chambers contained water at the same temperature and $\mathrm{pCO}_{2}$ conditions as in the experimental tanks. The light energy and photoperiod conditions were the same as for the acclimation tanks. Flow rate in all chambers was constantly maintained at 12 L.h $^{-1}$. Each chamber was equipped with a two-way electromagnetic valve activated by an automaton (FieldPoint National Instruments). When the electrovalve was opened, the water released from the chamber was analyzed for 3 min using an oxygen sensor (OXI 538, Cellox 325, WTW, Weilheim, Germany) to quantify dissolved oxygen. Oxygen measurements were performed over $48 \mathrm{~h}$. The first 8 hours of measurement were discarded due to the animal acclimatization to the chamber. In each chamber, the cycle was completed within 3 min: the first 2 min served to stabilize the measurement and an average of oxygen data was performed on the last minute of acquisition. This cycle was followed by another time frame of $3 \mathrm{~min}$ in the control chamber following the sequence: specimen \#1, control, specimen \#2, control, specimen \#3, control, specimen \#4, control. Respiration rate $(R R)$ and production rate $(P R)$ were calculated from data obtained during night- and day-time, respectively, using differences in oxygen concentrations between the control and experimental chambers. $\mathrm{RR}$ and $\mathrm{PR}=\mathrm{V}(\mathrm{O} 1-\mathrm{O} 2)$, with $\mathrm{O} 1$ the oxygen concentration in the control chamber, $\mathrm{O} 2$ the oxygen concentration in the experimental chamber, and $V$ the water flow rate. RR and PR data were normalized to tissue dry weight. Once normalized, the terminology becomes $\mathrm{O}_{2}$ consumption for $\mathrm{RR}$ and $\mathrm{O}_{2}$ production for $\mathrm{PR}$, both expressed in $\mathrm{mg} \mathrm{O}_{2} \cdot \mathrm{h}^{-1} \cdot \mathrm{g}^{-1}$ dry weight.

After $\mathrm{O}_{2}$ production and $\mathrm{O}_{2}$ consumption analyses were completed, a piece of the mantle was dissected for further symbiont fluorescence and density analyses (see section 2.5). The remaining soft tissues were frozen and lyophilized for RR and PR data normalization.

\subsection{Fluorescence and density measurements of symbionts}

190 Potential effect of temperature and $\mathrm{pCO}_{2}$ conditions on the photophysiology of the symbionts was studied by comparing fluorescence yield of photosystem II between all experimental conditions. After clams were sacrificed, a $1 \mathrm{~cm} \times 2 \mathrm{~cm}$ mantle fragment was dissected. The tissue fragment was gently swiped using tissue paper to remove a maximum of mucus and symbionts were collected by doing 5 smears using a sterilized razor blade. Collected symbionts were diluted into $5 \mathrm{~mL}$ of $0.2 \mu \mathrm{m}$ filteredseawater and placed at the obscurity for $10 \mathrm{~min}$ to inactive the photosystem II before light excitation. Samples were homogenized and $3 \mathrm{ml}$ of the homogenate were collected, placed into a quartz-glass cuvette and analyzed with AquaPen fluorometer (APC-100, Photon System Instruments ${ }^{\circledR}$, Czech Republic) at a $450 \mathrm{~nm}$ wavelength. The fluorescence at the steady state $\left(\mathrm{F}_{0}\right)$ and the maximal fluorescence in the light $\left(\mathrm{Fm}_{\mathrm{m}}\right)$ were measured. The apparent quantum yield of photosynthesis $(\mathrm{Y})$ reflecting the efficiency of photosystem II in the light acclimated state (Hoogenboom et al., 2006) was calculated according to equation (Eqn 1).

$$
Y=\frac{\left(F_{O}-F_{m}\right)}{F_{m}}
$$


In addition, symbiont densities were evaluated from mantle fragments. For each individual, a circular (5 $\mathrm{mm}$ diameter) piece of mantle was collected using a punch. The piece was weighted, grounded in 0.2 $\mu \mathrm{m}$ filtered seawater and homogenized. Then, $20 \mu \mathrm{L}$ of the tissue extract were immediately collected and placed into Mallassez cells for symbiont counting under optical microscope. For each sample, counting was performed on four replicates ( 3 columns per replicate). Data are expressed in number of symbionts/mg of mantle tissue.

\subsection{Calcein labelling for evaluating daily shell extension rate}

211 To study the impact of temperature and $\mathrm{pCO}_{2}$ on shell growth rate, the mineralization front of giant clams was marked using calcein fluorochrome which is irreversibly precipitated at the $\mathrm{CaCO}_{3}$ mineralization site. Before the experiment starts, giant clams were immersed in a $100 \mathrm{mg} / \mathrm{L}$ calcein solution (Sigma Aldrich) (calcein diluted in $1 \mu \mathrm{m}$ filtered-seawater) for $8 \mathrm{~h}$ in the dark. During the labelling procedure, the bath of calcein solution was aerated using bubblers and a water current was created via pumps. Calceinlabelled specimens were then placed into the experimental tanks. At the end of the experiment, for each individual, a $5 \mathrm{~mm}$ thick section was cut along the maximal shell growth axis through the right valve using a Swap Top Inland ${ }^{\circledR}$ diamond saw. All sections obtained were polished and observed under epifluorescence $\left(\lambda_{\text {excitation }}=495 \mathrm{~nm}, \lambda_{\text {emission }}=515 \mathrm{~nm}\right)$ with a Leitz Dialux ${ }^{\circledR} 22$ microscope. The distance between the fluorescent calcein mark and the edge of the shell formed during the experiment was measured following the maximal growth direction. Daily shell extension rate (expressed in $\mu \mathrm{m} / \mathrm{day}$ ) was obtained by dividing the measured distance by the number of days of incubation in experimental conditions.

\subsection{Shell scanning electron microscopy study}

226 To characterize temperature and $p \mathrm{CO}_{2}$ effect on the shell ultrastructure, a scanning electron microscopy 227 (SEM) study was carried out. For each individual, a $10 \mathrm{~mm}$ thick shell section was cut facing the section used for calcein observations. The section was then fractured along the width, $2 \mathrm{~cm}$ below the growing part of the shell (marginal part), using a small chisel and a hammer. Then, the apical fragment was

230 Iongitudinally fractured and one piece was sonicated in tap water for $10 \mathrm{~s}$, air-dried and an additional drying was done overnight at $35^{\circ} \mathrm{C}$. Sample was placed on a stub covered with carbon tape, gold-coated and observed at $15 \mathrm{kV}$ using a Hitachi TM3030 SEM at the Université de la Polynésie française. For each condition, and for each time of exposure, 2 samples were selected based on their daily extension rate, i.e., samples showing the lowest and the highest rate. To evaluate the impact of temperature and/or $\mathrm{pCO}_{2}$ on the shell ultrastructure, SEM observations were performed for each specimen in two different zones of the crossed-lamellar outer layer (Pätzold et al., 1991). Zone 1 corresponds to the shell formed

237 in situ (i.e., in the shell region located before the calcein mark) while zone 2 corresponds to the shell

238 formed during the experiment. Observations were made at the ultrastructural level and focused on the aspect and integrity of the lamellae of the crossed-lamellar outer layer. 


\subsection{Statistical analyses and data processing}

242 Normality of data distribution and homogeneity of variance were tested with the Shapiro-Wilk test and 243 the Bartlett test, respectively. Production and consumption of $\mathrm{O}_{2}$ data followed the conditions of 244 application of parametric tests, but photosynthetic yields and symbiont densities were transformed using 245 Box Cox transformation while shell extension rates were square root to meet these conditions. 246 Comparisons were done using a three-way ANOVA with interaction where factors were time of 247 exposure, temperature and $p \mathrm{CO}_{2}$. Tukey post hoc comparisons were done at $\alpha=0.05$ for all analyses. 248 Correlations between physiological parameters were tested using Pearson method with a threshold of $249 \quad \mathrm{r}=0.25(\alpha=0.05)$.

250 For all physiological parameters, i.e., $\mathrm{O}_{2}$ respiration, $\mathrm{O}_{2}$ consumption, symbiont photosynthetic yield and 251 density, means ( \pm s.d.) were calculated based on the 4 biological replicates for each condition and each 252 time of exposure. For the daily shell extension rate, means ( \pm s.d.) were calculated for each condition and each time of exposure.

\section{Results}

\subsection{Effect of temperature and $\mathrm{pCO}_{2}$ on the holobiont oxygen balance}

257 For all sampling time (i.e., 29, 41, 53, 65 days), a cyclic pattern of $\mathrm{O}_{2}$ production and consumption is observed following the circadian cycle (Fig. 1). This pattern corresponds to oxygen photosynthetically produced and heterotrophically consumed by the holobiont during the day and the night, respectively. Mean values of normalized $\mathrm{O}_{2}$ production and consumption are shown in Fig. 2. These values were analyzed using a three-way ANOVA with 3 fixed factors: temperature, $\mathrm{pCO}_{2}$, and the time of exposure (Table 2). Tukey post hoc test results are reported in Table 3. The ANOVA indicates that oxygen production of the holobiont during day-time is significantly altered at $30.7^{\circ} \mathrm{C}(P=0.009)$ but not at 1212 $\mu$ atm of $\mathrm{CO}_{2}(P=0.361)$ (Table 2). In addition, $\mathrm{O}_{2}$ production is higher at $29.2^{\circ} \mathrm{C}$ than at $30.7^{\circ} \mathrm{C}$ for all times of exposure (Fig. 2A) and decreases along the experiment $(P=0.030)$ (Table 2). The night-time $\mathrm{O}_{2}$ consumption, however, is not significantly influenced by temperature $(P=0.590)$ neither by $\mathrm{pCO}_{2}$ $(P=0.361)$ nor by time of exposure $(P=0.533)$ and remains stable along the whole experiment (Fig. $2 A, B)$. No interaction effect between the 3 tested factors is found to affect the holobiont oxygen balance (Table 2).

\subsection{Symbiont density and photosynthesis under different $\mathrm{T} / \mathrm{pCO}$ conditions} After two months of exposure, the symbiont photosynthetic yield and density are significantly impacted at $30.7^{\circ} \mathrm{C}(P<0.0001)$, high $p \mathrm{CO}_{2}(1212 \mu \mathrm{atm})(P<0.0001$ and $P=0.05$, respectively), and by the time of exposure $\left(P=0.021\right.$ and $P=0.001$, respectively). During the whole experiment and for both $p \mathrm{CO}_{2}$ conditions, the means of photosynthetic yield (Fig. 2C) and symbiont density (Fig. 2D) tend to be higher at $29.2^{\circ} \mathrm{C}$ than at $30.7^{\circ} \mathrm{C}$. However, an inter-individual variability is observed.

277 Concerning the interaction parameters, only interaction between temperature and time of exposure parameters has a significant effect on the symbiont photosynthetic yield $(P=0.025)$ (Table 2). No parameter interaction is found to affect the symbiont density (Table 2). 


\subsection{Negative effect of $\mathrm{pCO}_{2}$ on daily shell extension rate}

282 Calcein mark was detectable in 55 over 64 shell sections. Statistical analyses on shell extension rate 283 data indicate that $p \mathrm{CO}_{2}$ and the time of exposure have a significant effect on the shell extension rate $284(P=0.010$ and $P=0.007$, respectively) (Table 2 ). In the Fig. $2 \mathrm{E}$, the mean values of shell extension rates 285 tend to be lower at high $p \mathrm{CO}_{2}$.

\subsection{Relationship between physiological parameters}

288 To establish if relationships exist between the various physiological parameters measured, a correlation 289 matrix was generated (Table 4). The photosynthetic yield of symbionts is strongly correlated to their density $(r=0.667) . \mathrm{O}_{2}$ production is also strongly correlated to symbiont density $(r=0.482)$ and photosynthetic yield $(r=0.331)$. Concerning the circadian functioning of the holobiont, its nocturnal

292 oxygen need is strongly correlated to the diurnal $\mathrm{O}_{2}$ production $(\mathrm{r}=0.629)$. No significant correlation is found between shell extension rate and other physiological parameters.

\subsection{Effect of long-term exposure to temperature and $\mathrm{pCO}_{2}$ on the shell microstructure} Ultrastructural observations of shell fractures were done in two zones: zone 1 corresponding to the shell formed in situ (i.e., before the experiment) and zone 2 corresponding to the shell formed in the experimental conditions. The lamellae formed before the experiment (zone 1) are well-cohesive and display an elongated shape, a smooth surface, and sharp or slightly rounded outlines (Fig. 3A,B,C). For

300 all experimental conditions, no difference between zone 1 and 2 is observed for all samples exposed for 30129 days (Fig. 3A,D). From 41 days, the lamellae observed in the majority of shells formed during the 302 experiment (zone 2), in all temperature/ $\mathrm{pCO}_{2}$ conditions, appeared less cohesive with a pronounced 303 granular aspect of the surface (Fig. 3E,H) and/or less cohesive lamellae with a crazed-like aspect (Fig. $3043 \mathrm{~F}, \mathrm{I})$. Two states classifying ultrastructural differences between the shell formed before and during the 305 experiment were defined as follow: i) ND; no difference observed between zone 1 and 2, ii) D; difference 306 observed between zone 1 and 2. In total, 19 samples over 24 displayed differences in lamellae aspect 307 between both zones. Data are reported in Table 5.

\subsection{Effect of time of exposure on oxygen balance, biomineralization and symbionts photophysiology}

310 Time of exposure to thermal and acidification stress was shown to have a significant impact on $\mathrm{O}_{2}$ 311 production $(P=0.030)$, photosynthetic yield $(P=0.021)$, symbiont density $(P=0.001)$ and shell growth rate $312(P=0.007)$ (Table 2). Post hoc tests showed that the kinetics of thermal or acidification stress varies 313 depending on the physiological parameter measured: $\mathrm{O}_{2}$ production and photosynthetic yield are 314 significantly different between 29 and 65 days while symbiont density and shell growth rate are both 315 impacted from 53 days of exposure (Table 3 ). 


\section{Discussion}

318 In this present study, we investigated the physiological responses of Tridacna maxima (i.e., 4-years-old 319 specimens) to temperature and $\mathrm{pCO}_{2}$ conditions in the French Polynesian lagoons under nowadays 320 warmer season conditions and those predicted for 2100 by the IPCC $2014\left(+1.5^{\circ} \mathrm{C}\right.$ and $+800 \mu$ atm of $321 \mathrm{CO}_{2}$ ). Today thermal conditions are already and sufficiently stressful to induce an acclimatization 322 process pictured by a slight regulation of the symbiont density without the collapse of the photosynthesis. 323 However, if in the today conditions the giant clams are able to mount this acclimatory and efficient 324 response that enable to maintain their key physiological characteristics, the thermal and $p \mathrm{CO}_{2}$ conditions 325 of tomorrow appear to be much more stressful and sufficient to induce strong disturbances of the two 326 key functional compartments of the giant clam, its phototrophic symbiosis and its biomineralization. 327 Indeed, the $30.7^{\circ} \mathrm{C}$ treatments have significantly impacted the holobiont by inducing a strong bleaching 328 response illustrated by the reduction of its $\mathrm{O}_{2}$ production, symbiont density and photosynthetic yield. $329 \mathrm{High} \mathrm{pCO}_{2}\left(+800 \mu \mathrm{atm}\right.$ of $\left.\mathrm{CO}_{2}\right)$ was shown to alter the symbiont photosynthetic yield and density and to 330 affect its biomineralization process by decreasing the shell growth rate.

4.1. No synergetic effect between temperature and $\mathrm{pCO}_{2}$ on giant clam and symbiont physiological parameters

334 Increase of atmospheric $\mathrm{CO}_{2}$ impacts both the seawater temperature and $\mathrm{pH}$ inducing ocean warming 335 and acidification (Sabine et al., 2004, IPCC, 2014). Therefore, the analysis of the synergetic effect of 336 both stressors on marine bivalve physiology is crucial. Watson et al. (2012) investigated the synergetic 337 effect of ocean acidification and warming on the survival of $T$. squamosa juveniles over a 60 days 338 crossed-factor experiment. They reported that the combination of the highest $p \mathrm{CO}_{2}\left(+600 \mu \mathrm{atm}\right.$ of $\left.\mathrm{CO}_{2}\right)$ 339 and both moderate and highest seawater temperatures $\left(30.0^{\circ} \mathrm{C}\right.$ and $\left.31.5^{\circ} \mathrm{C}\right)$ resulted in the lowest 340 survival rate of giant clams (<20\%). They concluded that increased ocean $p \mathrm{CO}_{2}$ and temperature are 341 likely to reduce the survival of $T$. squamosa juveniles. In our study, no synergetic effect was detected 342 for all measured physiological parameters on T. maxima. Moreover, no mortality was observed in all 343 tested temperature/ $/ \mathrm{CO}_{2}$ conditions during the whole experiment which lead us to suggest that a 344 temperature of $30.7^{\circ} \mathrm{C}$ and a $p \mathrm{CO}_{2}$ of $1212 \mu \mathrm{atm}$ seem to be non-lethal, at least over 65 days of 345 exposure. However, we cannot exclude that some specimens, especially the totally bleached 346 individuals, may have died after a longer exposure to the experimental conditions.

4.2. Effect of temperature on holobiont oxygen balance, symbiont photophysiology and shell 349 ultrastructure

350 Temperature is a factor well-known to influence several physiological parameters in bivalves as it 351 regulates the metabolism of ectotherm organisms (Aldridge et al., 1995, Bougrier et al., 1995, Watson 352 et al., 2012, Gazeau et al., 2013; Le Moullac et al., 2016a; Latchère et al., 2017). However, since giant 353 clams live in symbiosis with photosynthetic symbionts (Klumpp et al., 1992; Klumpp and Griffits, 1994; 354 Soo and Todd, 2014), the comparison at the metabolic level with non-symbiotic bivalves can be 355 audacious. Discussion on elevated temperature effect on the holobiont oxygen balance should therefore 356 integrate the effect on both giant clam and its symbionts (Jones and Hoegh-Guldberg, 2001). Even 
though physiological and molecular response to thermal stress may differ, the comparison with scleractinian corals, which are also symbiotic and calcifying organisms, makes sense to better understand the impact of temperature on the holobiont physiology.

We observed that high temperature $\left(+1.5^{\circ} \mathrm{C}\right)$ significantly reduces the holobiont $\mathrm{O}_{2}$ production, the density and the photosynthetic yield of symbionts from 29 days of exposure. Additionally, partial or total bleaching was observed for the majority of individuals exposed to $30.7^{\circ} \mathrm{C}$ (at both ambient and high $\mathrm{pCO}_{2}$, Fig. S2). This suggests that thermal stress has a significant impact on the holobiont photophysiology. The reduction of the symbiont photosynthetic yield could reflect a photoinhibition. Photoinhibition was previously linked to the degradation of the D1 protein of the reaction center of the photosystem II (PSII) altering the photosynthetic apparatus functioning in symbiotic corals and sea anemone subjected to thermal stress (Warner et al., 1999; Smith et al., 2005; Richier et al., 2006; Ferrier-Pagès et al., 2007). Diminution of photosynthetic activity reduces the symbiont $\mathrm{O}_{2}$ production and consequently, impacts the holobiont $\mathrm{O}_{2}$ production. Comparable results were obtained from a 24hour experiment showing that an increase of $3^{\circ} \mathrm{C}$ affects the oxygen production of Tridacna gigas and Tridacna deresa (Blidberg et al., 2000). Photoinhibition led to the production of reactive oxygen species (ROS) by symbionts which are known to pass through cellular membranes, cause oxidative damages (Lesser et al., 1990; Lesser, 1996; Downs et al., 2002) and impact the photosystem II (Richter et al., 1990). Considering corals, a strong positive correlation between accumulation of oxidative damage and coral bleaching was shown (Downs et al., 2002). Indeed, ROS such as hydrogen peroxide $\left(\mathrm{H}_{2} \mathrm{O}_{2}\right)$ may play a role of signaling molecule activating the symbiosis dissociation (Fitt et al., 2001; Smith et al., 2005; Perez and Weis, 2006). Expulsion of symbionts by the host may be a strategy to limit oxidative stress and damage to ultimately survive environmental stress (Downs et al., 2002; Perez and Weis, 2006). Two recent works support this hypothesis. One of Zhou et al. (2018) which related a decrease in symbiont density in response to an excess of oxidative stress in thermally stressed $T$. crocea. A second of Dubousquet et al. (2016) which showed that T. maxima overexpressed genes encoding ROS scavengers in response to thermal stress. Interestingly, the cellular and molecular mechanisms enhanced upstream the bleaching response seem similar between giant clams and corals and conduct to the same phenomenon of symbiosis dissociation. However, since giant clams and corals display an extra- and an intra-cellular symbiosis respectively, the mechanisms of the symbiosis dissociation must differ. In every instance, this constitutes an interesting example of evolutionary convergence of a stress response in two very distant organisms. In this context, it would be interesting to test if the bleaching response in giant clam can be adaptive as it was proposed for corals (Fautin and Buddemeier, 2004) and if variations in giant clam thermo-tolerance are correlated to the composition of the symbiotic population (Baker, 2003).

391 Concerning the effect of temperature on the ultrastructure of the crossed-lamellar structure, the lamellae formed in all experimental conditions in the first 29 days are well-cohesive with elongated shape and a granular aspect which is consistent with the description made by Agbaje et al. (2017) in T. deresa.

394 However, after 29 days, the lamellae observed in the majority of shells formed in both temperature conditions (whatever the $\mathrm{pCO}_{2}$ condition) appeared to be less-cohesive with pronounced granular aspect. We suggest that these features are due to a lack of organic matrix between the lamellae (i.e., 
inter-lamellar organic matrix) and embedding the nano-grains forming the first-order lamellae in the crossed-lamellae structure (as described by Agbaje et al., 2017). Indeed, the biomineralization of calcium carbonate structures involved the transport of ions (calcium, bicarbonates and protons) to the mineralization site and the synthesis of macromolecules referred to as "organic matrix" (Allemand et al., 2004). The organic matrix, consisting of $0.9 \%$ weight of $T$. deresa shell, and is mainly composed of assemblage of macromolecules such as polysaccharides, glycosylated, and unglycosylated proteins and lipids (Agbaje et al., 2017). These macromolecules are commonly found in molluscan shell organic matrix (Marin et al., 2012) present as inter-crystalline envelope and around individual crystal units (Harper, 2000). The formation of these macromolecules is energetically costly for mollusks such as marine gastropods (Palmer, 1992). According to the conclusion made by Milano et al. (2016) in the nonsymbiotic bivalve Cerastoderma edule, we suggest that in our tested experimental temperature, while respiration function is significantly altered, less energy is available and allocated to the synthesis of macromolecules involved in biomineralization which may explained the lack of organic matrix embedded into the giant clam shell.

\subsection{Effect of $\mathrm{pCO}_{2}$ on giant clam biomineralization and symbiont photophysiology}

413 Ocean acidification is related to an increase of dissolved $\mathrm{CO}_{2}$ in the seawater resulting in a modification 414 of carbonate chemistry equilibrium and a decrease of seawater $\mathrm{pH}$. This phenomenon is known to affect 415 biomineralization process of marine calcifiers since the production of biocarbonate structures depends 416 on both calcium carbonate saturation state and on the ability to express proteins involved in 417 biomineralization (Fitzer et al., 2014). The $\mathrm{pCO}_{2}$ is a well-known parameter to influence mollusk 418 calcification process in terms of growth rate, expression of gene encoding proteins involved in 419 biomineralization, and to alter the integrity of biocarbonate structures (Welladsen et al., 2010; Melzner 420 et al., 2011; Fitzer et al., 2014; Le Moullac et al., 2016b), even if counter examples exist (Ries et al., 421 2009; Kroeker et al., 2010).

422 Concerning giant clams, our results indicate that in high $\mathrm{pCO}_{2}$ condition ( $\left.+800 \mu \mathrm{atm}\right)$, shell extension 423 rate decreases significantly. This observation is in accordance with those obtained for giant clams in 424 three different experiments using various $\mathrm{CO}_{2}$ enrichment level and exposure duration. Waters (2008) 425 and Watson (2015) have exposed juveniles T. squamosa to $+200 \mu$ atm of $\mathrm{CO}_{2}$ for 13 weeks and to +250 426 and $+550 \mu \mathrm{atm}$ of $\mathrm{CO}_{2}$ for 8 weeks, respectively. Toonen et al. (2012) demonstrated that young 427 specimens of T. maxima and T. squamosa have lower shell growth rates, compared to those reported 428 in the literature under natural $p \mathrm{CO}_{2} / \mathrm{pH}$ conditions, when kept 1 year in +350 to $+1000 \mu \mathrm{atm} p \mathrm{CO}_{2}$ 429 conditions.

430 As mentioned above, high $\mathrm{pCO}_{2}$ condition (+800 $\left.\mu \mathrm{atm}\right)$ affects giant clam shell growth rate but also 431 symbiont photosynthetic yield and density. Negative effect of $\mathrm{pCO}_{2}$ on the shell growth rate may be 432 linked to (1) the aragonite saturation state which is lower at $1212 \mu \mathrm{atm}$ than at $430 \mu \mathrm{atm}$ and/or (2) an 433 alteration of symbiont photophysiology leading to a potential reduction of the 'light-enhanced 434 calcification' (LEC). Concerning the former, decline of coral calcification rate has been related to 
modifications of carbonate chemistry due to a limitation of $\mathrm{CO}_{3}{ }^{2-}$ ions available for calcification. Even if corals may upregulate the $\mathrm{pH}$ at their mineralization site (Venn et al., 2013; Holcomb et al., 2014), the decrease of coral calcification was also linked to a decline in $\mathrm{pH}$ in the calcifying fluid due to a lower seawater pH (Ries et al., 2011; McCulloch et al., 2012). In our case, we suggest that giant clam $T$. maxima exposed to high $\mathrm{pCO}_{2}$ may allocate more energy to maintain a proper $\mathrm{pH}$ of the fluid in the extra-pallial space for nucleation and deposition of aragonite since the $\Omega_{\text {aragonite }}$ at high $p \mathrm{CO}_{2}$ is twice lower than at ambient $\mathrm{pCO}_{2}$ ( $($ aragonite, $1212 \mu \mathrm{atm}=2, \Omega$ aragonite, $430 \mu \mathrm{atm}=4$ ). Regarding the light-enhanced calcification (LEC) (Vandermeulen et al., 1972), this phenomenon observed in Symbiodiniaceae-host symbiosis has been extensively described in corals and represents the capacity of symbionts to stimulate the host calcification (Allemand et al., 2004). The symbionts stimulate the host metabolism and calcification by providing energy resources and/or $\mathrm{O}_{2}$ (Chalker and Taylor, 1975). Moreover, symbionts may promote the aragonite precipitation by providing inorganic carbon, nitrogen and phosphorus and by synthetizing molecules used as precursor for the synthesis of skeletal organic matrix (Pearse and Muscatine, 1971; Cuif et al., 1999; Furla et al., 2000; Muscatine et al., 2005). They also facilitate $\mathrm{CaCO}_{3}$ precipitation by influencing the Dissolved Inorganic Carbon (DIC) equilibrium by removing the $\mathrm{CO}_{2}$ via photosynthesis (Goreau, 1959). Such phenomenon has been also described in giant clams (Ip et al., 2006; Ip et al., 2017). In T. squamosa, LEC increases the pH and reduces the ammonia concentration at the interface between the inner mantle and the shell in the extra-pallial fluid, where the biomineralization occurs (Ip et al., 2006). Recently, Chew et al. (2019) reported a lightenhanced expression of a carbonic anhydrase (i.e., CA4-like) in the inner mantle of $T$. squamosa and suggested that this enzyme is involved in giant clam biomineralization by catalyzing the conversion of $\mathrm{HCO}_{3}{ }^{-}$to $\mathrm{CO}_{2}$. In this context, an altered photophysiology of the symbiont can rationally alter LEC and consequently results in a decrease of the shell growth rate. Finally, one can suggest that under acidification stress, giant clam may reduce or stop some physiological functions such as biomineralization and allocate more energy to essential functions to its survival. In our study, temperature also altered photophysiology and holobiont $\mathrm{O}_{2}$ production, but did not significantly affect shell growth rate. Therefore, the most plausible hypothesis explaining the negative effect of $p \mathrm{CO}_{2}$ on shell growth rate may be related to the low aragonite saturation state at high $p \mathrm{CO}_{2}$.

Concerning the effect of $\mathrm{pCO}_{2}$ on the shell microstructural integrity, in the temperate bivalve Mytilus edulis, an exposition to $+150,+350$ and $+600 \mu$ atm of $\mathrm{CO}_{2}$ for 6 months induced a disorientation in the shell of the newly formed calcite crystals of the prismatic layer (Fitzer et al., 2014). In the giant clam $T$. maxima, high $\mathrm{pCO}_{2}$ had no negative effect on the integrity of the aragonitic lamellae of the crossedlamellar layer during the first 29 days of exposure. From 41 days of exposure, its potential impact remains unresolved as differences were noticed in the shells formed under future high temperature, high $p \mathrm{CO}_{2}$ and even under today high temperature/ $/ \mathrm{PCO}_{2}$ conditions. The fact that differences are reported

470 for shells formed in all experimental conditions from 41 days suggests that they may be due to a longterm exposure to $29.2^{\circ} \mathrm{C}$ and $30.7^{\circ} \mathrm{C}$. 
This study enables the evaluation of Tridacna maxima physiological responses to temperature and $p \mathrm{CO}_{2}$ thresholds predicted at the end of this century. We demonstrated that high temperature has a significant negative impact on symbiont densities and photosynthetic capacities, which induce a decrease in holobiont $\mathrm{O}_{2}$ production rate. We suggest that the observed decrease of holobiont $\mathrm{O}_{2}$ production rate results from a decrease of symbiont $\mathrm{O}_{2}$ production. Therefore, by influencing symbiont physiology, the temperature may affect the energetic needs of the giant clam host. The high $p \mathrm{CO}_{2}$ has a negative impact on shell growth rate, symbiont densities and photosynthetic capacities. Shell microstructure is affected neither by temperature nor by the $\mathrm{pCO}_{2}$ in the first 29 days of exposure. However, for all temperature/ $p \mathrm{CO}_{2}$ conditions, a longer exposition ( $\geq 41$ days) modified the shell ultrastructure. These observations support our hypothesis that $29.2^{\circ} \mathrm{C}$ is a temperature that already affects giant clam metabolism, at least over a long-term exposition. However, no synergetic effect was found between temperature and $p \mathrm{CO}_{2}$ parameters. All these observations suggest that temperature and $p \mathrm{CO}_{2}$ influence different physiological functions and that giant clam populations may dramatically suffer from the temperature and $p \mathrm{CO}_{2}$ conditions predicted for the next decades. To complement these results on the effects of temperature on the holobiont, it is now essential to conduct further and integrative analyses. This may include the definition of thermal optimum of T. maxima and the study of the transcriptomic response of the giant clam and its symbiotic Symbiodiniaceae to thermal stress for instance. All these analyses will allow a better understanding of the fundamental physiological processes of the holobiont and its response to future changes. Attempted results may also help in adapting local policies and management to maintain a sustainable exploitation of giant clam resource, especially in the Eastern Tuamotu islands where bleaching events have been observed at an increasing and alarming rate.

\section{Acknowledgments}

497 The authors would like to thank Celine Lafabrie for fruitful discussions and Mickael Mege and Alexia 498 Pihier for their technical assistance. Georges Remoissenet (Direction of Marine Resources of French 499 Polynesia) is thanked for sharing information about bleaching events in Eastern Tuamotu islands. The 500 Direction of Marine Resources and the Ministry of Economic Recovery, Blue Economy and Digital Policy of French Polynesia are also thanked for according the special permit to collect and hold small specimens of Tridacna maxima species. This study is set within the framework of the "Laboratoires d'Excellence (LabEX)" TULIP (ANR-10-LABX-41).

504

\section{Competing interests}

506 The authors declare no competing interests.

\section{$508 \quad$ Funding}

509 This work was financially supported by the Ifremer institution (Politique de site program, GECO project) 510 and the University of French Polynesia (MAPIKO and CLAMS projects). 


\section{References}

Adessi, L. (2001). Giant clam bleaching in the lagoon of Takapoto atoll (French Polynesia). Coral Reefs 19, 220.

Agbaje, O.B.A., Wirth, R., Morales, L.F.G., Shirai, K., Kosnik, M., Watanabe, T. and Jacob, D.E. (2017). Architecture of crossed-lamellar bivalve shells: the southern giant clam (Tridacna deresa, Röding, 1798). R. Soc. Open Sci. 4, 170622

Allemand, D., Ferrier-Pagès, C., Furla, P., Houlbreque, F., Puverel, S., Reynaud, S. Tambutté, E., Tambutté, S and Zoccola, D. (2004). Biomineralisation in reef-building corals: from molecular mechanisms to environmental control. C.R. Palevol. 3, 453-467.

Alcazat, S.N. (1986). Observations on predators of giant clams (Bivalvia: family Tridacnidae). Silliman J. 33, 54-57.

Aldridge, D.W., Payne, B.S. and Miller, A.C. (1995). Oxygen-consumption, nitrogenous excretion, and filtration-rates of Dreissena polymorpha at acclimation temperatures between 20 and 32 degrees. Can. J. Fish. Aquat. Sci. 52, 1761-1767.

Amstrong, E. (2017) lon-regulatory and developmental physiology of giant clams (Genus Tridacna) and their conservation status on the island of Mo'orea, French Polynesia. PhD thesis, University of Berkley, USA.

Andréfouët, S., Van Wynsberge, S., Gaertner-Mazouni, N., Menkes, C., Gilbert, A. and Remoissenet, G. (2013). Climate variability and massive mortalities challenge giant clam conservation and management efforts in French Polynesia atolls. Biol. Conserv. 160,190-199.

Andréfouët, S., Dutheil, C., Menkes, C.E., Bador, M. and Lengaigne, M. (2015). Mass mortality events in atoll lagoons: environmental control and increased future vulnerability. Glob. Chang. Biol. 21, 95-205.

Andréfouët, S., Van Wynsberge, S., Kabbadj, L., Wabnitz, C.C.C., Menkes, C., Tamata, T., Pahuatini, M., Tetairekie, I., Teaka, I., Ah Scha, T., Teaka, T. and Remoissenet, G. (2017). Adaptative management for the sustainable exploitation of lagoon resources in remote islands: lessons from a massive el Nino-induced giant clam bleaching event in the Tuamotu atolls (French Polynesia). Env. Conserv. 45, 30-40.

Baker, A. C. (2003). Flexibility and specifity in coral-algual symbiosis: Diversity, ecology, and biogeography of Symbiodinium. Annu. Rev. Ecol. Evol. Syst. 34, 661-689.

Bell, J.D., Lane, I., Gervis, M., Soule, S. and Tafea, H. (1997) Village-based farming of the giant clam Tridacna gigas (L.), for the aquarium market: Initial trials in Solomon Islands. Aquacult. Res. 28, $121-128$

Blidberg, E., Elfwing, T., Planhnan, P. and Tedengren, M. (2000). Water temperature influences on physiological behaviour in three species of giant clams (Tridacnidae). Proceeding $9^{\text {th }}$ International Coral Reef Symposium, Bali, Indonesia, 1.

Broeker, W.S., Takahashi, T., Simpson, H.J. and Peng, T.-H. (1979). Fate of fossil fuel carbon dioxide and the global carbon budget. Science 206, 409-418. 
Bougrier, S., Geairon, P., Deslouspaoli, J.M., Bacher, C. and Jonquieres, G. (1995). Allometric relationships and effects of temperature on clearance and oxygene consumption rates of Crassostrea gigas (Thunberg). Aquaculture 134, 143-154.

Buck, B.H., Rosenthal, H. and Saint-Paul, U. (2002). Effect of increased irradiance and thermal stress on the symbiosis of Symbiodinium microadriaticum and Tridacna gigas. Aquat. Living Resour. 15, 107-117.

Caldeira, K. and Wickett, M.E. (2003). Anthropogenic carbon and ocean pH. Nature 425, 365.

Chalker, B.E. and Taylor, D.L. (1975). Light-enhanced calcification, and the role of oxidative phosphorylation in calcification of the coral Acropora cervicornis. Proc. R. Soc. Lond. 190, 323331.

Chew, S.F., Koh, C.Z.Y., Hiong, K.C., Choob, C.Y.L, Wong, W.P., Neo, M.L. and Ip, Y. (2019). Light-enhanced expression of Carbonic Anhydrase 4-like supports shell formation in the fluted giant clam Tridacna squamosa. Gene 683, 101-112.

Cuif, J.-P., Dauphin, Y., Freiwald, A., Gautret and P., Zibrowius, H. (1999). Biochemical markers of zooxanthellae symbiosis in soluble matrices of skeleton of 24 Scleractinia species. Comp. Biochem. Physiol. 123A, 269-278.

DeBoer, T.S., Baker, A.C., Erdmann, M.V., Jones, P.R., and Barber, P.H. (2012). Patterns of Symbiodinium distribution in three giant clam species across the biodiverse Bird's Head region of Indonesia. Mar. Ecol. Prog. Ser. 444,117-132.

Downs, C.A., Fauth J.E., Halas, J.C., Dustan, P., Bemiss, J. and Woodley, C.M. (2002). Oxidative stress and seasonal coral bleaching. Free Radic. Biol. Med. 33, 533-543.

Dubousquet, V., Gros, E., Berteaux-Lecellier, V., Viguier, B., Raharivelomanana, P., Bertrand, C. and Lecellier, G. (2016). Changes in fatty acid composition in the giant clam Tridacna maxima in response to thermal stress. Biol. Open. 5, 1400-1407.

Elfwing, T., Blidberg, E. and Tedengren, M. (2002). Physiological responses to copper in giant clams: a comparison of two methods in revealing effects on photosynthesis in zooxanthellae. Mar. Environ. Res. 54, 147-155.

Fautin, D. and Buddemeier, R. (2004). Adaptive bleaching: a general phenomenon. Hydrobiologia 530, 459-467.

Ferrier-Pages, C., Richard, C., Forcioli, D., Allemand, D., Pichon, M. and Shick, J.M. (2007). Effects of temperature and UV radiation increases on the photosynthetic efficiency in four scleractinian coral species. Biol. Bulletin. 213, 76-87.

Fitt, W.K., Brown, B.E., Warner, M.E. and Dunne, R.P. (2001). Coral bleaching: interpretation of thermal tolerance limits and thermal thresholds in tropical corals. Coral Reefs 20, 51-65.

Fitzer, S. C., Phoenix, V.R., Cusack, M. and Kamenos, N. A. (2014). Ocean acidification impacts mussel control on biomineralisation. Sci. Reports 4, 6218.

586 Furla, P., Galgani, I., Durand, I. and Allemand, D. (2000). Sources and mechanisms of inorganic carbon transport for coral calcification and photosynthesis. J. Exp. Biol. 203, 3445-3457. 
Gazeau, F., Gattuso, J., Dawber, C., Pronker, A., Peene, F., Peene, J., Heip, C. and Middelburg, J. (2010) Effect of ocean acidification on the early life stages of the blue mussel Mytilus edulis. Biogeosciences 7, 2051-2060.

Gazeau, F., Parker, L.M., Comeau, S., Gattuso, J., O'Connor, W., Martin, S., Portner, H.and Ross, P.M. (2013). Impacts of ocean acidification on marine shelled molluscs. Mar. Biol. 160, 2207-2245.

Goreau, T.F. (1959). The physiology of skeleton formation in corals. I. A method for measuring the rate of calcium deposition by corals under different conditions. Biol. Bull. 116, 59-75.

Harper, E.M. (2000). Are calcitic layers an effective adaptation against shell dissolution in the Bivalvia? J. Zool. 251, 179e186.

601

602

603

604

605

606

607

608

609

610

Hawkins, A.J.S. and Klumpp, D.W. (1995) Nutrition of the giant clam Tridacna gigas (L.). II. Relative contributions of filter-feeding and the ammonium-nitrogen acquired and recycled by symbiotic alga towards total nitrogen requirements for tissue growth and metabolism. J. Exp. Mar. Biol. Ecol. 190, 263-290.

Hoegh-Guldberg, O., Mumby, P.J., Hooten, A.J., Steneck, R.S., Greenfield, P., Gomez, E., Harvell, C.D., Sale, P.F., Edwards, A.J., Caldeira, et al. (2007). Coral reefs under rapid climate change and ocean acidification. Science 318, 1737-1742.

Holcomb, M., Venn, A., Tambutté, E., Tambutté, S., Allemand, D., Trotter, J. and McCulloch, M. (2014). Coral calcifying fluid $\mathrm{pH}$ dictates response to ocean acidification. Sci. Reports 4, 5207.

Holt, A.L., Vahidinia, S., Gagnon, Y.L., Morse, D.E. and Sweeney, A.M. (2014). Photosymbiotic giant clams are transformers of solar flux. J. Royal Soc. Interface 11, 20140678.

Ikeda, S., Yamashita, H., Kondo, S., Inoue, K., Morishima, S., Koike, K. (2017). Zooxanthellal genetic varieties in giant clams are partially determined by species-intrinsic and growth-related characteristics. PLoS One 12, e0172285.

Ip, Y.K., Loong, A.M., Hiong, K.C., Wong, W.P., Chew, S.F., Reddy, K., Sivaloganathan, B. and Ballantyne, J.S. (2006). Light induces an increase in the $\mathrm{pH}$ of and a decrease in the ammonia concentration in the extrapallial fluid of the giant clam Tridacna squamosa. Physiol. Biochem. Zool. 79, 656-664.

Ip, Y.K., Hiong, K.C., Goh, E.J.K., Boo, M.V., Choo, Y.L., Ching, B., Wong, W.P. and Chew, S.F. (2017). The whitish inner mantle of the giant clam, Tridacna squamosa, expresses an apical Plasma Membrane $\mathrm{Ca}^{2+}$-ATPase (PMCA) which displays light-dependent gene and protein expressions. Front. Physiol. 8, 781.

IPCC (2014). Summary for policymakers. In Climate Change 2014: Impacts, Adaptation, and Vulnerability. Part A: Global and Sectoral Aspects. Contribution of Working Group II to the Fifth Assessment Report of the Intergovernmental Panel on Climate Change (ed. C.B. Field, V.R. Barros, D.J. Dokken, K.J. Mach, M.D. Mastrandrea, T.E. Bilir, M. Chatterjee, K.L. Ebi, Y.O. Estrada, R.C. Genova, B. Girma, E.S. Kissel, A.N. Levy, S. MacCracken, P.R. Mastrandrea and L.L. White), pp. 1-32. Cambridge, UK and New York, NY, USA: Cambridge University Press. 
IPCC (2018) Summary for Policymakers. In Global warming of $1.5^{\circ} \mathrm{C}$. An IPCC Special Report on the impacts of global warming of $1.5^{\circ} \mathrm{C}$ above pre-industrial levels and related global greenhouse gas emission pathways, in the context of strengthening the global response to the threat of climate change, sustainable development, and efforts to eradicate poverty. (ed. V. MassonDelmotte, P. Zhai, H. O. Pörtner, D. Roberts, J. Skea, P. R. Shukla, A. Pirani, W. MoufoumaOkia, C. Péan, R. Pidcock, S. Connors, J. B. R. Matthews, Y. Chen, X. Zhou, M. I. Gomis, E. Lonnoy, T. Maycock, M. Tignor, T. Waterfield), pp. 1-32. World Meteorological Organization, Geneva, Switzerland.

Ishikura, M., Adachi, K. and Maruyama, T. (1999). Zooxanthellae release glucose in the tissue of a giant clam, Tridacna crocea. Mar. Biol. 133, 665-673.

Jones, R.J. and Hoegh-Guldberg, O. (2001). Diurnal changes in the photochemical efficiency of the symbiotic dinoflagellates (Dinophyceae) of corals: photoprotection, photoinactivation and the relationship to coral bleaching. Plant Cell and Environ. 24, 89-99.

Junchompoo, C., Sinrapasan, N., Penpain, C. and Patsorn, P. (2013). Changing seawater temperature effects on giant clams bleaching, Mannai Island, Rayong province, Thailand. Proceedings of the Design Symposium on Conservation of Ecosystem (The 12th SEASTAR2000 workshop), 7176.

Kleypas, J. A. (1999). Geochemical Consequences of Increased Atmospheric Carbon Dioxide on Coral Reefs. Science 284, 118-120.

Klumpp, D.W., Bayne, B.L. and Hawkins, A.J.S. (1992). Nutrition of the giant clam Tridacna gigas. Contribution of filter feeding and photosynthates to respiration and growth. J. Exp. Mar. Biol. Ecol. 155, 105-122.

Klumpp, D.W. and Griffiths, C.L. (1994). Contributions of phototrophic and heterotrophic nutrition to the metabolic and growth requirements of four species of giant clam (Tridacnidae). Mar. Ecol. Prog. Ser. 115, 103-115.

Klumpp, D.W. and Lucas, J.S. (1994). Nutritional ecology of the giant clams Tridacna tevoroa and T. derasa from Tonga - Influence of light on filter-feeding and photosynthesis. Mar. Ecol. Prog. Ser. 107, 147-156.

Kroeker, K.J., Kordas, R.L., Crim, R.N. and Singh, G.G. (2010). Meta-analysis reveals negative yet variable effects of ocean acidification on marine organisms. Ecol. Letters. 13, 1419-1434.

Kurihara, $\mathrm{H}$. (2008). Effects of $\mathrm{CO}_{2}$-driven ocean acidification on the early developmental stages of invertebrates. Mar. Ecol. Prog. Ser. 373, 275-284.

Kurihara, T., Yamada, H., Inoue, K., Iwai, K. and Hatta, M. (2013). Impediment to symbiosis establishment between giant clams and Symbiodinium algae due to sterilization of seawater. PLoS One 8, e61156.

LaJeunesse, T. C., Parkinson, J. E., Gabrielson, P. W., Jeong, H. J., Reimer, J. D., Voolstra, C. R., and Santos, S. R. (2018). Systematic revision of Symbiodiniaceae highlights the antiquity and diversity of coral endosymbionts. Current Biology 28, 2570-2580.e6. 
Latchère, O., le Moullac, G., Gaetner-Mazouni, N., Fievet, J., Magré, K. and Saulnier, D. (2017). Influence of preoperative food and temperature conditions on pearl biogenesis in Pinctada margaritifera. Aquaculture 479, 176-187.

Leggat, W., Buck, B.H., Grice, A. and Yellowlees, D. (2003). The impact of bleaching on the metabolic contribution of dinoflagellate symbionts to their giant clam host. Plant Cell Environ. 26, 19511961.

Le Moullac, G., Soyez, C., Latchere, O., Vidal-Dupiol, J., Fremery, J., Saulnier, D., Lo Yat, A., Belliard, C., Mazouni-Gaertner N., and Gueguen, Y. (2016a). Pinctada margaritifera responses to temperature and $\mathrm{pH}$ : acclimation capabilities and physiological limits. Estuar. Coast Shelf Sci. 182, 261-269.

Le Moullac, G., Soyez C., Vidal-Dupiol, J., Belliard, C., Fievet, J. Sham-Koua, M., Lo Yat, A., Saulnier, D., Gaertner-Mazouni, N. et al. (2016b). Impact of pCO2 on the energy, reproduction and growth of the shell of the pearl oyster Pinctada margaritifera. Estuar. Coast Shelf Sci. 182, 274-282.

Lesser, M.P. (1996). Elevated temperatures and ultraviolet radiation cause oxidative stress and inhibit photosynthesis in symbiotic dinoflagellates. Limnol. Oceanog. 41, 271-283.

Lesser, M.P., Stochaj, W.R., Tapley, D.W. and Schick, J.M. (1990). Bleaching in coral reef anthozoans: Effects of irradiance, ultraviolet radiation and temperature on the activities of protective enzymes against active oxygen. Coral Reefs 8, 225-232.

Lim, S.S.Q., Huang, D., Soong, K., and Neo, M.L. (2019). Diversity of endosymbiotic Symbiodiniaceae in giant clams at Dongsha Atoll, northern South China Sea. Symbiosis doi:10.1007/s13199-01900615-5.

Lin, A.Y.M., Meyers, M.A. and Vecchio, K.S. (2006). Mechanical properties and structure of Strombus gigas, Tridacna gigas, and Haliotis rufescens sea shells: a comparative study. Mater. Sci. Eng. A. Struct. Mater. 26, 1380-1389.

Liu, W., Huang, X., Lin, J. and He, M. (2012). Seawater acidification and elevated temperature affect gene expression patterns of the pearl oyster Pinctada fucata. PLoS One 7, e33679.

Lucas, J.S. (1994). The biology, exploitation, and mariculture of giant clams (Tridacnidae). Rev. Fisheries Science 2, 181-223.

Marin, F., Le Roy, N. and Marie, B. (2012). Formation and mineralization of mollusk shell. Front. Biosci. 4, 1099-1125.

McCulloch, M., Falter, J., Trotter, J. and Montagna, P. (2012). Coral resilience to ocean acidification and global warming through $\mathrm{pH}$ up-regulation. Nature Clim. Change 2, 623-627.

Melzner, F., Stange, P., Trübenbach, K., Thomsen, J., Casties, I., Panknin, U., Gorb, S. and Gutowska, M. (2011) Food Supply and Seawater $\mathrm{pCO}_{2}$ Impact Calcification and Internal Shell Dissolution in the Blue Mussel Mytilus edulis. PLoS One 6, e24223.

Mies, M., Dor, P., Güth, A.Z. and Sumida, P.Y.G. (2017). Production in giant clam aquaculture: Trends and Challenges. Rev. Fish. Sci. Aquac. 25, 286-296. 
Milano, S., Schöne, B.R., Wang, S. and Müller, W.E. (2016). Impact of high $\mathrm{pCO}_{2}$ on shell structure of the bivalve Cerastoderma edule. Mar. Envir. Res. 119, 144-155.

702

703

704

705

706

707

708

709

710

711

712

713

714

715

716

717

718

719

720

721

722

723

724

725

726

727

728

729

730

731

732

733

734

735

736

Muscatine, L., Goiran, C., Land, L., Jaubert, J., Cuif, J.P. and Allemand, D. (2005). Stable isotopes (delta C-13 and delta N-15) of organic matrix from coral skeleton. Proc. Nation. Acad. Sci. USA. 102, 1525-1530.

Neo, M.L., Eckman, W., Vicentuan, K., Teo, S.L.M. and Todd, P.A. (2015). The ecological significance of giant clams in coral reef ecosystems. Biol. Conserv. 181,111-123.

Norton, J.H., Shepherd, M.A., Long, H.M. and Fitt, W.K. (1992). The zooxanthellal tubular system in the giant clam. Biol Bull. 183, 503-506.

Orr, J.C., Fabry, V.J., Aumont, O., Bopp, L., Doney, S.C., Feely, R.A., Gnanadesikan, A., Gruber, N., Ishida, A., Joos, F. et al. (2005). Anthropogenic ocean acidification over the twenty-first century and its impact on calcifying organisms. Nature 437, 681-686.

Palmer, A.R. (1992). Calcification in marine molluscs: how costly is it? Proc. Natl. Acad. Sci. USA. 89, 1379-1382.

Pätzold, J., Heinrichs, J.P., Wolschendorf, K. and Wefer, G. (1991). Correlation of stable oxygen isotope temperature record with light attenuation profiles in reef-dwelling Tridacna shells. Coral Reefs 10, 65- 69.

Pearse, V.B. and Muscatine, L. (1971). Role of symbiotic algae (zooxanthellae) in coral calcification. Biol. Bull. 141, 350-363.

Perez, S. and Weis, V. (2006). Nitric oxide and cnidarian bleaching: an eviction notice mediates breakdown of a symbiosis. J. Exp. Biol. 209, 2804-2810.

Pinzón, J.H., Devlin-Durante, M.K., Weber, M.X., Baums, I.B., and LaJeunesse, T.C. (2011). Microsatellite loci for Symbiodinium A3 (S. fitti) a common algal symbiont among Caribbean Acropora (stony corals) and Indo-Pacific giant clams (Tridacna). Conserv. Genet. Resour. 3 , 45-47.

Richier, S., Sabourault, C., Courtiade, J., Zucchini, N., Allemand, D. and Furla, P. (2006). Oxidative stress and apoptotic events during thermal stress in the symbiotic sea anemone, Anemonia viridis. Febs Journal 273, 4186-4198.

Richter C, Rühle, W. and Wild, A. (1990). Studies on the mechanisms of photosystem II photoinhibition II. The involvement of toxic oxygen species. Photosynthesis Res. 24, 237-243.

Ries, J.B., Cohen, A.L. and McCorkle, D.C. (2009). Marine calcifiers exhibit mixed responses to $\mathrm{CO}_{2}-$ induced ocean acidification. Geology 37, 1131-1134.

Ries, J.B. (2011) A physiochemical framework for interpreting the biological calcification response to $\mathrm{CO}_{2}$-induced ocean acidification. Geochim Cosmochim Acta 75, 4053-4064.

Rodolfo-Metalpa, R., Houlbreque, F., Tambutte, E., Boisson, F., Baggini, C., Patti, F.P., Jeffree, R., Fine, M., Foggo, A., Gattuso, J.P. et al. (2011). Coral and mollusc resistance to ocean acidification adversely affected by warming. Nature Clim. Change 1, 308-312. 
Sabine, C.L., Feely, R.A., Gruber, N., Key, R.M., Lee, K., Bullister, J.L., Wanninkhof, R., Wong, C.S., Wallace, D.W.R., Tilbrook, B. et al. (2004). The oceanic sink for anthropogenic $\mathrm{CO}_{2}$. Science 305, 367-371.

Schwartzmann, C., Durrieu, M., Sow, M., Ciret, P., Lazareth, C.E. and Massabuau, J.-C. (2011) In situ giant clam growth rate behavior in relation to temperature: A one-year couple study of highfrequency noninvasive valvometry and scleraochronology. Limnol. Ocean. 56, 1940-1951.

Smith, D.J., Suggett, D.J. and Baker, N.R. (2005). Is photoinhibition of zooxanthellae photosynthesis the primary cause of thermal bleaching in corals? Global Change Biology 11, 1-11.

Soo, P. and Todd, P.A. (2014). The behaviour of giant clams. Mar. Biol. 161, 2699-2717.

Talmage, S.C. and Gobler, C.J. (2011). Effects of elevated temperature and carbon dioxide on the growth and survival of larvae and juveniles of three species of northwest Atlantic bivalves. PLoS One 6, e26941.

Toonen, R.J., Nakayama, T., Ogawa, T., Rossiter, A. and Delbeek, J.C. (2012). Growth of cultured giant clams (Tridacna spp.) in low $\mathrm{pH}$, high nutrient seawater: species-specific effects of substrate and supplemental feeding under acidification. J. Mar. Biol. Assoc. UK. 92, 731-740.

Vandermeulen, J.H., Davis, N.D. and Muscatine, L. (1972). The effect of inhibitors of photosynthesis on zooxanthellae in corals and other marine invertebrates. Mar. Bio. 16, 185-191.

van Heuven, S., Pierrot, D., Lewis, E. and Wallace, D.W.R. (2009). MATLAB Program developed for $\mathrm{CO}_{2}$ system calculations, ORNL/CDIAC-105b, Carbon Dioxide Information Analysis Center, Oak Ridge National Laboratory, US Department of Energy, Oak Ridge, Tennessee.

Van Wynsberge, S., Andréfouët, S., Gaertner-Mazouni, N., Wabnitz, C.C.C., Gilbert, A., Remoissenet,

Venn, A., Tambutté, E., Holcomb, M., Laurent, J. Allemand, D. and Tambutté, S. (2013). Impact of seawater acidification on $\mathrm{pH}$ at the tissue-skeleton interface and calcification in reef corals. PNAS 110, 1634-1639.

Warner, M.E., Fitt, W.K., and Schmidt, G.W. (1999). Damage to photosystem II in symbiotic

Waters, C.G. (2008). Biological responses of juvenile Tridacna maxima (Mollusca:Bivalvia) to increased

Watson, S. (2015). Giant Clams and rising $\mathrm{CO}_{2}$ : Light may ameliorate effects of ocean acidification on a solar-powered animal. PLoS One 10, e0128405. of ocean acidification on shell characteristics of Pinctada fucata (Bivalvia: Pteriidae). Molluscan Res. 30, 125-130. 
775 Yau, A.J.Y. and Fan, T.Y. (2012). Size-dependent photosynthetic performance in the giant clam Tridacna maxima, a mixotrophic marine bivalve. Mar. Biol. 159, 65-75.

777 Zeebe, R.E., Zachos, J.C., Caldeira, K. and Tyrrell, T. (2008). Oceans-Carbon emissions and 778 acidification. Science $321,51-52$.

779 Zhou, Z., Liu, Z., Wang, L., Luo, J. and Li, H. (2019) Oxidative stress, apoptosis activation and symbiosis 780 disruption in giant clam Tridacna crocea under high temperature. Fish. Fish. Immunol. 84, 451457. 


\section{$782 \quad$ Figure and table legends}

783

784 Table 1. Measured and calculated parameters of seawater for all treatments. Total alkalinity is 785 given in mean ( \pm s.d.) based on weekly measurements for each experimental tank corresponding to $786 \mathrm{n}=36$ for each condition. $\mathrm{pCO}_{2}$ and $\Omega$ aragonite were calculated using the $\mathrm{CO}_{2}$ Systat software.

787

\begin{tabular}{lcccccc}
\hline Treatments & $\begin{array}{c}\text { Temperature } \\
\left({ }^{\circ} \mathrm{C}\right)\end{array}$ & $\begin{array}{c}\mathrm{pCO}_{2} \\
(\mu \mathrm{atm})\end{array}$ & $\mathrm{pH}_{\mathrm{NBS}}$ & $\begin{array}{c}\text { Salinity } \\
(\%)\end{array}$ & $\begin{array}{c}\text { Total alkalinity } \\
(\mu \mathrm{mol} / \mathrm{kg} \mathrm{SW})\end{array}$ & $\mathbf{\Omega}_{\text {aragonite }}$ \\
\hline Control & $29.2( \pm 0.1)$ & $428( \pm 21)$ & $8.19( \pm 0.01)$ & 35 & $2422( \pm 170)$ & 4.17 \\
Thermal stress & $30.7( \pm 0.1)$ & $431( \pm 25)$ & $8.19( \pm 0.01)$ & 35 & $2409( \pm 157)$ & 4.14 \\
Acidification stress & $29.2( \pm 0.1)$ & $1210( \pm 41)$ & $7.81( \pm 0.03)$ & 35 & $2466( \pm 90)$ & 1.99 \\
$\begin{array}{l}\text { Acidification and thermal } \\
\text { stress }\end{array}$ & $30.7( \pm 0.1)$ & $1213( \pm 29)$ & $7.81( \pm 0.03)$ & 35 & $2423( \pm 110)$ & 2.02 \\
\hline
\end{tabular}




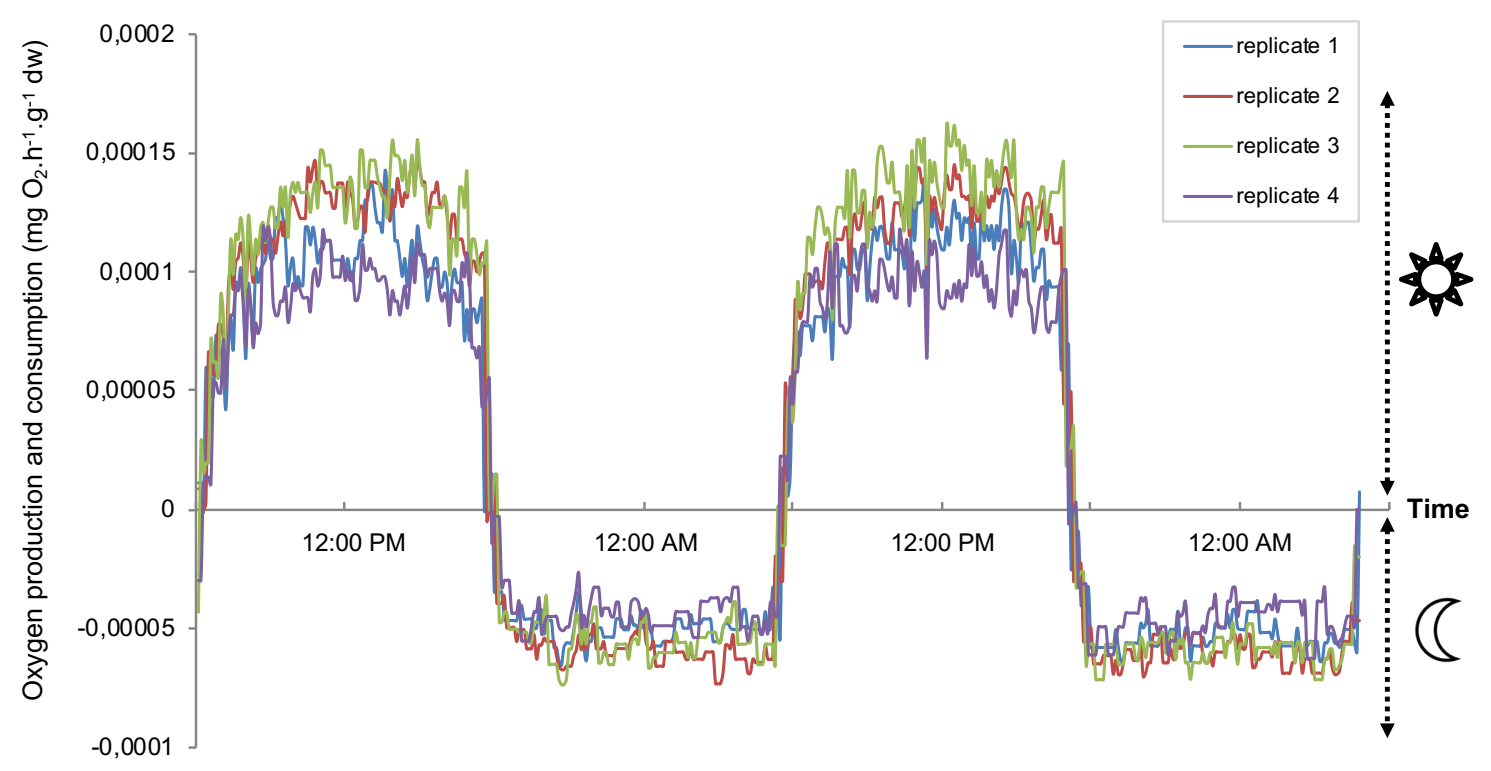

790 Figure 1. Variations of oxygen consumption and oxygen production acquired over a $48 \mathrm{~h}$ period

791 after 29 days of exposure to $29.2^{\circ} \mathrm{C}$ and $430 \mu$ atm of $\mathrm{CO}_{2}$. Data are expressed in $\mathrm{mg} \mathrm{O} \cdot \mathrm{O}^{-1} \cdot \mathrm{g}^{-1}$ tissue dry weight $(\mathrm{dw})$ and correspond to day-time and night-time acquisitions for 4 giant clam replicates. 


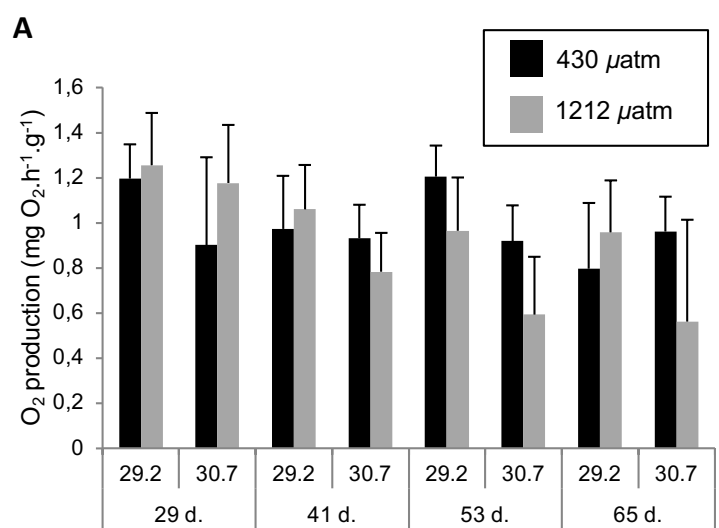

C

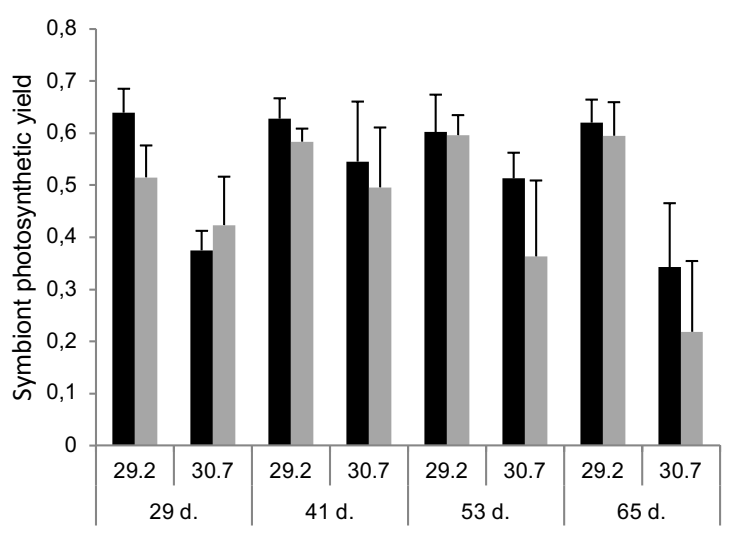

E

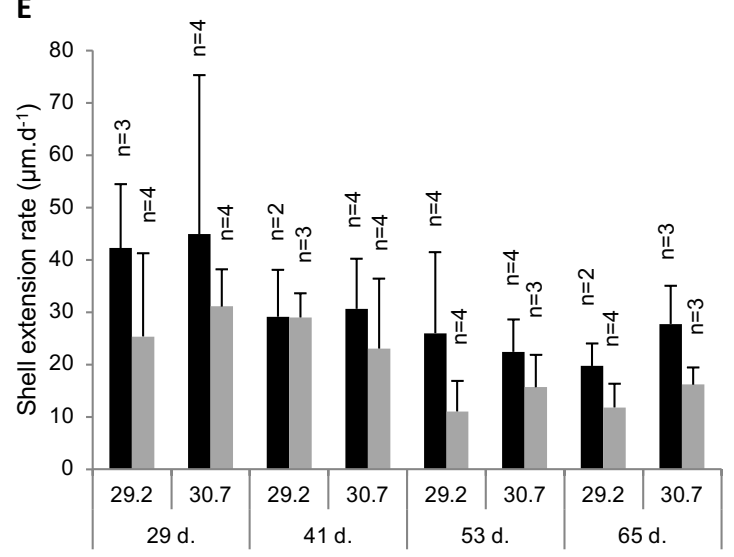

B

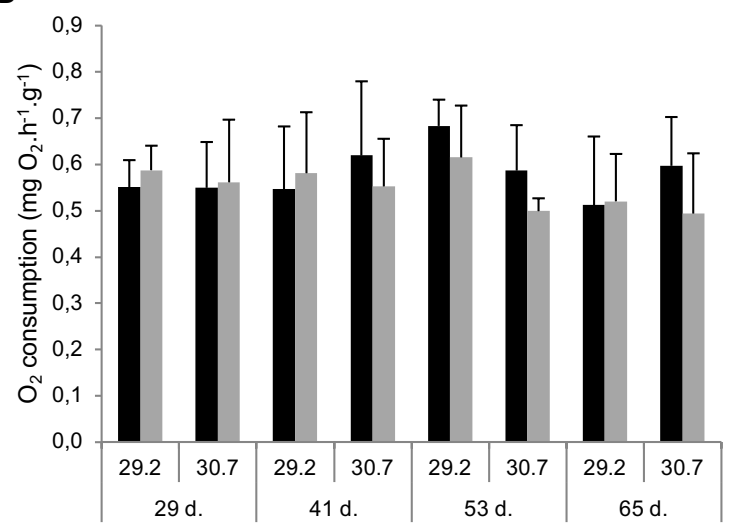

D

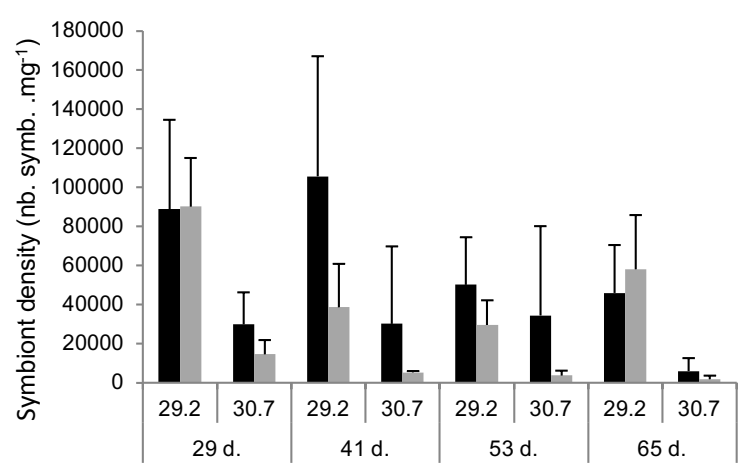

Figure 2. Graphs reporting data of (A) oxygen production, (B) oxygen consumption, (C) symbiont photosynthethic yield and (D) density, and (E) daily shell extension rate obtained for each temperature/ $\mathrm{pCO}_{2}$ experimental condition and time of exposure. Black and grey columns correspond to today $\mathrm{pCO}_{2}$ condition $(430 \mu \mathrm{atm})$ and future $\mathrm{pCO}_{2}$ condition (1212 $\left.\mu \mathrm{atm}\right)$, respectively. Data are given in mean (+s.d.) calculated from 4 replicates $(n=4)$ for each physiological parameter excepted for daily shell extension rate. For this latter parameter, numbers of replicates are indicated on the graph. 
803 Table 2. Results from the three-way ANOVA performed on holobiont $\mathrm{O}_{2}$ production and 804 consumption data, symbiont photosynthetic yield, symbiont density, and giant clam shell 805 extension rate. The three fixed factors are $\mathrm{pCO}_{2}$, temperature and time of exposure.

806 Significant differences $(P<0.05)$ are highlighted in grey.

807

\begin{tabular}{|c|c|c|c|c|c|c|}
\hline & & $\begin{array}{c}\mathrm{O}_{2} \\
\text { production } \\
(\mathrm{n}=64)\end{array}$ & $\begin{array}{c}\mathrm{O}_{2} \\
\text { consumption } \\
(n=64)\end{array}$ & $\begin{array}{c}\text { Photosynthetic } \\
\text { yield } \\
(n=64)\end{array}$ & $\begin{array}{l}\text { Symbiont } \\
\text { density } \\
(n=64)\end{array}$ & $\begin{array}{c}\text { Shell extension } \\
\text { rate } \\
(n=55)\end{array}$ \\
\hline \multirow{2}{*}{ Time } & $F$ & 3.264 & 0.740 & 3.566 & 6.035 & 4.695 \\
\hline & $P$ & 0.030 & 0.533 & 0.021 & 0.001 & 0.007 \\
\hline \multirow{2}{*}{ Temperature } & $F$ & 7.551 & 0.294 & 65.200 & 79.158 & 0.466 \\
\hline & $P$ & 0.009 & 0.590 & $<0.0001$ & $<0.0001$ & 0.499 \\
\hline \multirow{2}{*}{$\mathrm{pCO}_{2}$} & $F$ & 0.846 & 0.851 & 6.125 & 8.665 & 7.409 \\
\hline & $P$ & 0.362 & 0.361 & 0.017 & 0.005 & 0.010 \\
\hline \multirow{2}{*}{ Time $x$ Temperature } & $F$ & 0.413 & 0.965 & 3.393 & 1.528 & 0.319 \\
\hline & $P$ & 0.744 & 0.417 & 0.025 & 0.219 & 0.812 \\
\hline \multirow{2}{*}{ Time $x p \mathrm{CO}_{2}$} & $F$ & 1.765 & 0.476 & 0.024 & 1.033 & 0.251 \\
\hline & $P$ & 0.167 & 0.700 & 0.995 & 0.386 & 0.860 \\
\hline \multirow{2}{*}{ Temperature $\mathrm{x} \mathrm{pCO}_{2}$} & $F$ & 1.334 & 1.029 & 0.100 & 1.989 & 0.026 \\
\hline & $P$ & 0.254 & 0.315 & 0.753 & 0.165 & 0.872 \\
\hline \multirow{2}{*}{ Time $\times$ Temperature $\times \mathrm{pCO}_{2}$} & $F$ & 1.216 & 0.148 & 2.153 & 0.474 & 0.336 \\
\hline & $P$ & 0.314 & 0.930 & 0.106 & 0.702 & 0.799 \\
\hline
\end{tabular}


809 Table 3. Results from Tukey post hoc tests following the three-way ANOVA performed on 810 analyzed physiological parameters. The effects of significant parameters were tested as time of 811 exposure alone and combined to the temperature. The letter annotations correspond to the significances

812 between conditions $(P<0.005)$.

813

\begin{tabular}{|c|c|c|c|c|c|}
\hline & & $\begin{array}{c}\mathrm{O}_{2} \\
\text { production }\end{array}$ & $\begin{array}{c}\text { Photosynthetic } \\
\text { yield }\end{array}$ & $\begin{array}{l}\text { Symbiont } \\
\text { density }\end{array}$ & $\begin{array}{l}\text { Shell extension } \\
\text { rate }\end{array}$ \\
\hline \multirow{4}{*}{ Time } & $29 \mathrm{~d}$ & $a$ & $a$ & $a$ & $a$ \\
\hline & $41 \mathrm{~d}$. & $a b$ & $a b$ & $a b$ & $a b$ \\
\hline & $53 \mathrm{~d}$ & $a b$ & $a b$ & $b$ & $b$ \\
\hline & $65 \mathrm{~d}$ & $\mathrm{~b}$ & $\mathrm{~b}$ & b & b \\
\hline \multirow{2}{*}{ Temperature } & $29.2^{\circ} \mathrm{C}$ & $a$ & $a$ & $a$ & - \\
\hline & $30.7^{\circ} \mathrm{C}$ & $\mathrm{b}$ & $\mathrm{b}$ & $\mathrm{b}$ & - \\
\hline \multirow{2}{*}{$\mathrm{pCO}_{2}$} & $430 \mu \mathrm{atm}$ & - & $a$ & $a$ & $a$ \\
\hline & $1212 \mu \mathrm{atm}$ & - & $\mathrm{b}$ & $\mathrm{b}$ & $b$ \\
\hline \multirow{8}{*}{ Time $x$ Temperature } & $29 \mathrm{~d} . \times 29.2^{\circ} \mathrm{C}$ & - & $a b$ & - & - \\
\hline & $41 \mathrm{~d} . \times 29.2^{\circ} \mathrm{C}$ & - & a & - & - \\
\hline & 53 d. $\times 29.2^{\circ} \mathrm{C}$ & - & a & - & - \\
\hline & 65 d. $\times 29.2^{\circ} \mathrm{C}$ & - & a & - & - \\
\hline & 29 d. $\times 30.7^{\circ} \mathrm{C}$ & - & $\mathrm{cd}$ & - & - \\
\hline & $41 \mathrm{~d} . \times 30.7^{\circ} \mathrm{C}$ & - & $a b c$ & - & - \\
\hline & $53 \mathrm{~d} . \times 30.7^{\circ} \mathrm{C}$ & - & bcd & - & - \\
\hline & $65 \mathrm{~d} . \times 30.7^{\circ} \mathrm{C}$ & - & d & - & - \\
\hline
\end{tabular}

814 
815 Table 4. Correlation matrix integrating the different physiological parameters monitored, i.e., $\mathbf{O}_{2}$ 816 production and consumption, shell extension rate and symbiont photosynthetic yield and 817 density. Correlation were tested using the Pearson method (threshold of $r=0.250, \alpha=0.05$ ) and 818 significant relationships between parameters are highlighted in grey.

\begin{tabular}{l|cccc}
\hline & $\begin{array}{c}\text { Photosynthetic } \\
\text { yield } \\
(\mathrm{n}=64)\end{array}$ & $\begin{array}{c}\text { Symbiont } \\
\text { density } \\
(\mathrm{n}=64)\end{array}$ & $\begin{array}{c}\text { Shell extension } \\
\text { rate } \\
(\mathrm{n}=55)\end{array}$ & $\begin{array}{c}\mathbf{O}_{2} \\
\text { production } \\
(\mathrm{n}=64)\end{array}$ \\
\hline Symbiont density & 0.667 & & & \\
Shell extension rate & -0.032 & 0.168 & 0.221 & 0.629 \\
$\mathrm{O}_{2}$ production & 0.331 & 0.492 & 0.129 & \\
$\mathrm{O}_{2}$ consumption & 0.163 & 0.226 & & \\
\hline
\end{tabular}


zone 1
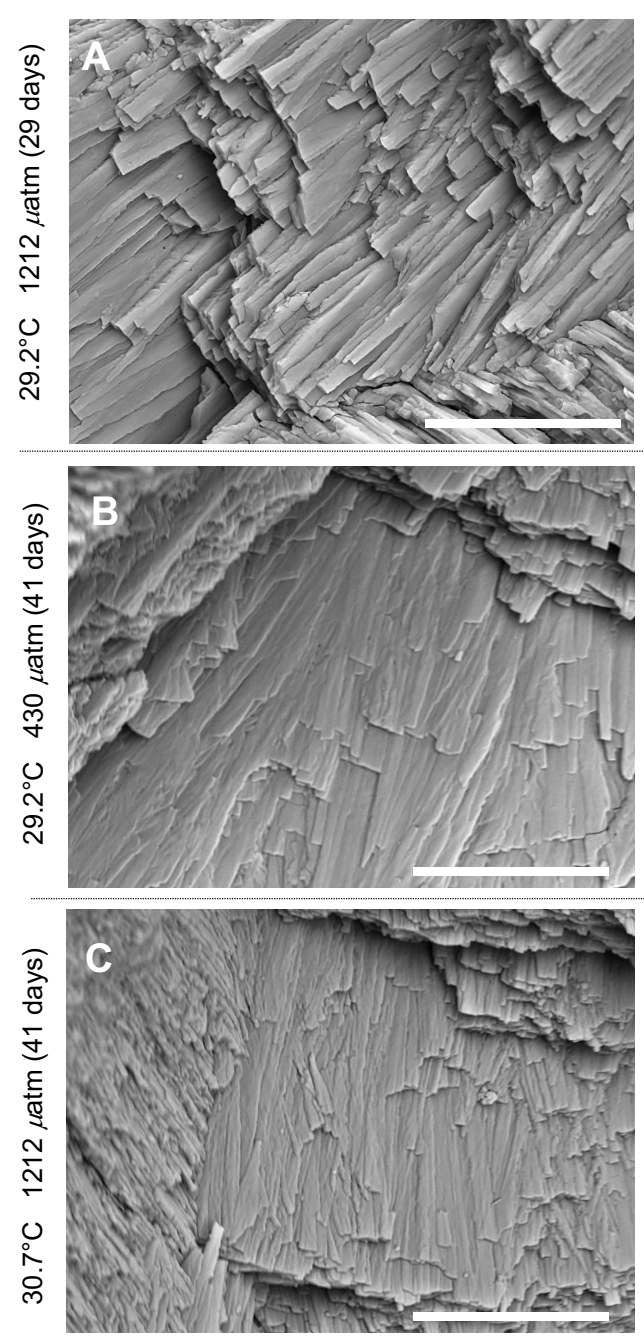

zone 2
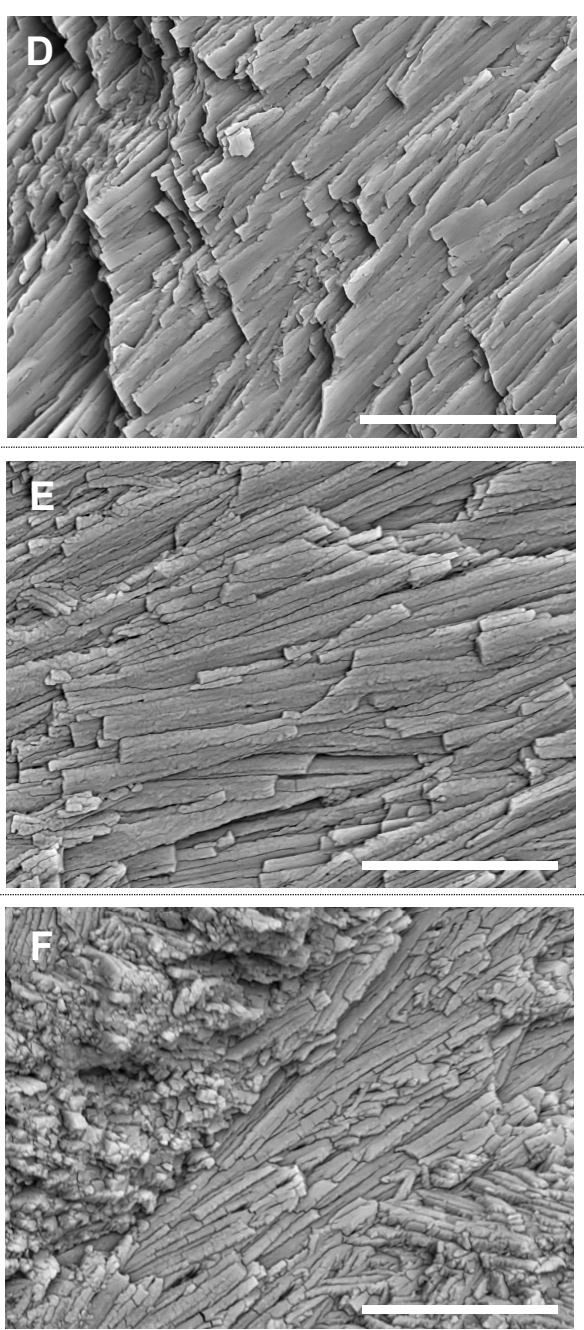

zoom on zone 2
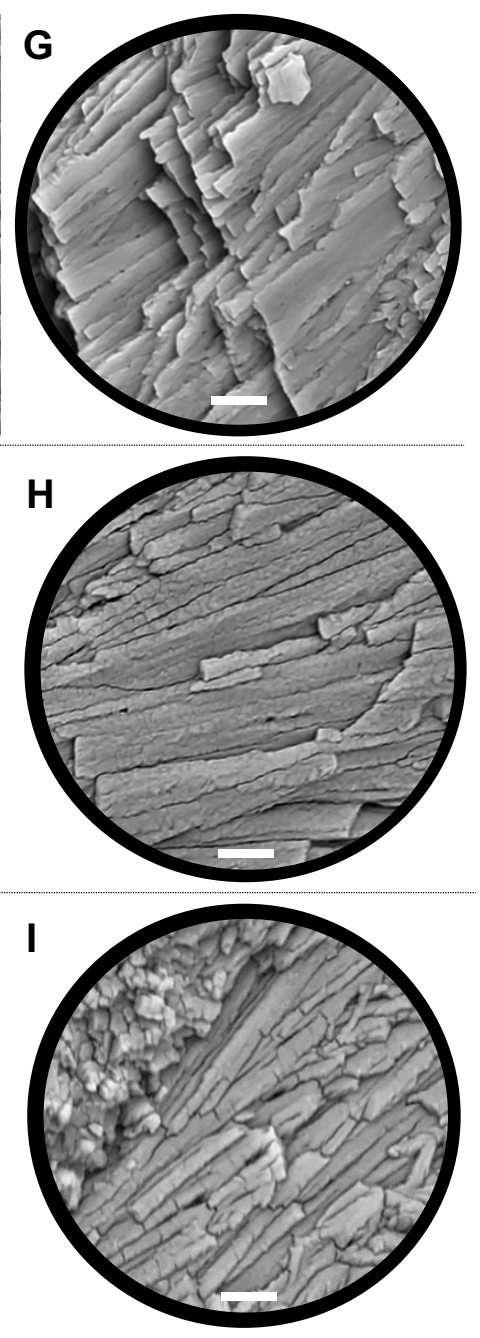

Figure 3. Effects of experimental conditions on the ultrastructure of the Tridacna maxima shell

821 outer layer investigated via scanning electron microscopy. (A-F: scale bar: $10 \mu \mathrm{m}, \mathrm{G}-\mathrm{I}$ : scale bar:

$8222 \mu \mathrm{m}$ ). Zone 1 and zone 2 correspond to the shell formed in situ (i.e., before the experiment) and in the

823 experimental conditions, respectively. (A, B and G): $29.2^{\circ} \mathrm{C} 1212 \mu \mathrm{atm}$ ( 29 days): no difference between

824 zone 1 and 2 . In both zones, lamellae are well-cohesive, displaying elongated shape with a smooth

825 surface and slightly rounded outlines. (B, E and $\mathrm{H}$ ) $29.2^{\circ} \mathrm{C} 430 \mu \mathrm{atm}$ (41 days): lamellae in zone 2 are

826 less-cohesive, with a pronounced granular aspect. (C, $\mathrm{F}$ and I) $30.7^{\circ} \mathrm{C} 430 \mu$ atm (41 days): lamellae in

827 zone 2 are less-cohesive and display crazes. 
829 Table 5. Compilation of ultrastructural observations of the lamellae of the shell outer layer using

830 scanning electron microscopy. "ND" means that no significant difference is observed between the

831 shell formed before and during the experiment. "D" means that a notable difference is observed between

832 both parts of the shell. "A" and "B" represent the two samples observed for each treatment and time of 833 exposure.

834

\begin{tabular}{|c|c|c|c|c|}
\hline Time of exposure & $\begin{array}{c}\text { Temperature } \\
\left({ }^{\circ} \mathrm{C}\right)\end{array}$ & $\begin{array}{c}\text { pCO}_{2} \\
(\mu \text { atm })\end{array}$ & Sample & Difference \\
\hline \multirow{8}{*}{29 d. } & \multirow{2}{*}{29.2} & \multirow{2}{*}{430} & $A$ & ND \\
\hline & & & B & ND \\
\hline & \multirow{2}{*}{30.7} & \multirow{2}{*}{430} & A & ND \\
\hline & & & B & ND \\
\hline & \multirow{2}{*}{29.2} & \multirow{2}{*}{1212} & $A$ & ND \\
\hline & & & B & ND \\
\hline & \multirow{2}{*}{30.7} & \multirow{2}{*}{1212} & A & ND \\
\hline & & & B & ND \\
\hline \multirow{8}{*}{$41 \mathrm{~d}}$. & \multirow{2}{*}{29.2} & \multirow{2}{*}{430} & $A$ & D \\
\hline & & & B & D \\
\hline & \multirow{2}{*}{30.7} & \multirow{2}{*}{430} & $A$ & $D$ \\
\hline & & & B & D \\
\hline & \multirow{2}{*}{29.2} & \multirow{2}{*}{1212} & $A$ & D \\
\hline & & & B & D \\
\hline & \multirow{2}{*}{30.7} & \multirow{2}{*}{1212} & $A$ & $D$ \\
\hline & & & $\mathrm{B}$ & ND \\
\hline \multirow{8}{*}{$53 \mathrm{~d}}$. & \multirow{2}{*}{29.2} & \multirow{2}{*}{430} & A & $D$ \\
\hline & & & $B$ & D \\
\hline & \multirow{2}{*}{30.7} & \multirow{2}{*}{430} & A & D \\
\hline & & & $\mathrm{B}$ & D \\
\hline & \multirow{2}{*}{29.2} & \multirow{2}{*}{1212} & A & ND \\
\hline & & & $B$ & D \\
\hline & \multirow{2}{*}{30.7} & \multirow{2}{*}{1212} & A & D \\
\hline & & & $\mathrm{B}$ & ND \\
\hline \multirow{8}{*}{$65 \mathrm{~d}}$. & \multirow{2}{*}{29.2} & \multirow{2}{*}{430} & $A$ & $D$ \\
\hline & & & $B$ & D \\
\hline & 307 & 130 & A & D \\
\hline & 30.1 & 430 & $\mathrm{~B}$ & ND \\
\hline & 292 & 1212 & $A$ & $D$ \\
\hline & & & $\mathrm{B}$ & D \\
\hline & 7 & 1210 & $A$ & ND \\
\hline & 30.1 & 1212 & B & D \\
\hline
\end{tabular}



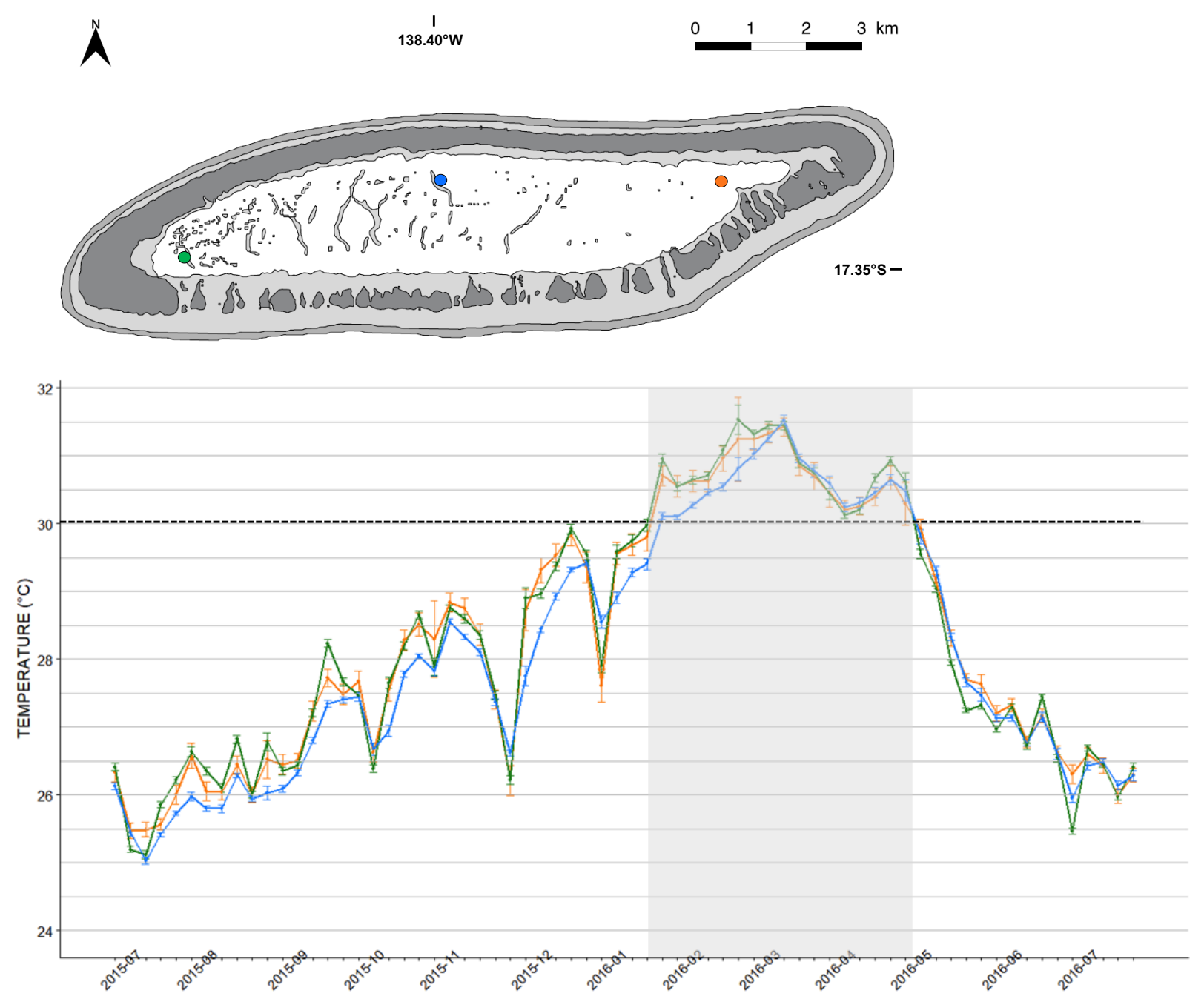

838 Figure S1. In situ seawater temperatures recorded from July 2015 to July 2016 inside the lagoon

839 of Tatakoto atoll (Tuamotu islands) at $\mathbf{2} \mathbf{m}$ depth. Temperature were recorded using UA-002-64

840 HOBO Onset data loggers. Curves on the graph report data from 3 sites localized on the map by circles

841 with corresponding color. Grey rectangle highlights the period when giant clams were exposed to a

842 temperature $\geq 30^{\circ} \mathrm{C}$. 

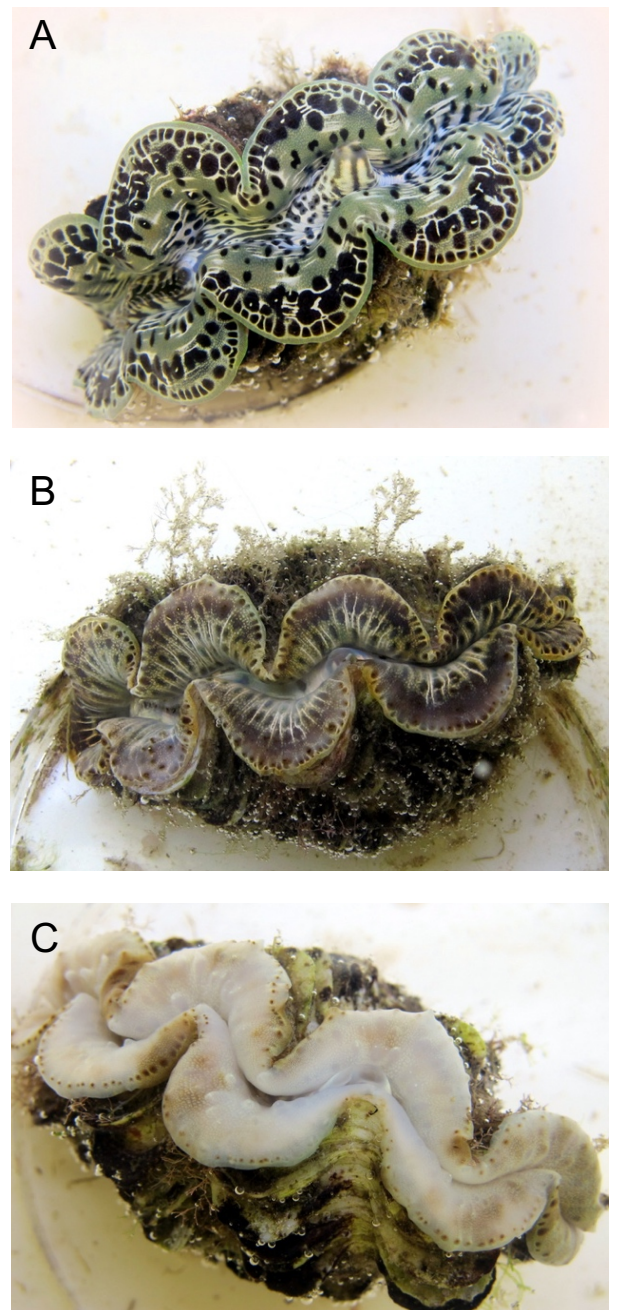

844 Figure S2. Visual observation of bleaching in giant clam Tridacna maxima specimens after 65 845 days in experimental conditions. (A) Non-bleached specimen exposed to $29.2^{\circ} \mathrm{C} 430 \mu \mathrm{atm}$ of $\mathrm{CO}_{2}$, 846 (B) partially bleached and (C) completely bleached specimens exposed to $30.7^{\circ} \mathrm{C} 1212 \mu \mathrm{atm}$ of $\mathrm{CO}_{2}$. 